\title{
Antidumping Law and Competition Law---China's Position?
}

\author{
by \\ Yang Liu, B.A. (Hons.)
}

\author{
A thesis submitted to \\ the Faculty of Graduate Studies and Research \\ in partial fulfillment of \\ the requirements for the degree of
}

Master of Arts

Department of Law

Carleton University

Ottawa, Ontario

November $24^{\text {th }}, 2005$

(C) 2005, Yang Liu 


$\begin{array}{ll}\begin{array}{l}\text { Library and } \\ \text { Archives Canada }\end{array} & \begin{array}{l}\text { Bibliothèque et } \\ \text { Archives Canada }\end{array} \\ \begin{array}{l}\text { Published Heritage } \\ \text { Branch }\end{array} & \begin{array}{l}\text { Direction du } \\ \text { Patrimoine de l'édition }\end{array} \\ \begin{array}{l}\text { 395 Wellington Street } \\ \text { Ottawa ON K1A ON4 }\end{array} & \begin{array}{l}\text { 395, rue Wellington } \\ \text { Ottawa ON K1A ON4 } \\ \text { Canada }\end{array} \\ \end{array}$

Your file Votre référence ISBN: 0-494-13416-X

Our file Notre référence

ISBN: 0-494-13416-X

NOTICE:

The author has granted a nonexclusive license allowing Library and Archives Canada to reproduce, publish, archive, preserve, conserve, communicate to the public by telecommunication or on the Internet, loan, distribute and sell theses worldwide, for commercial or noncommercial purposes, in microform, paper, electronic and/or any other formats.

The author retains copyright ownership and moral rights in this thesis. Neither the thesis nor substantial extracts from it may be printed or otherwise reproduced without the author's permission.
AVIS:

L'auteur a accordé une licence non exclusive permettant à la Bibliothèque et Archives Canada de reproduire, publier, archiver, sauvegarder, conserver, transmettre au public par télécommunication ou par l'Internet, prêter, distribuer et vendre des thèses partout dans le monde, à des fins commerciales ou autres, sur support microforme, papier, électronique et/ou autres formats.

L'auteur conserve la propriété du droit d'auteur et des droits moraux qui protège cette thèse. $\mathrm{Ni}$ la thèse ni des extraits substantiels de celle-ci ne doivent être imprimés ou autrement reproduits sans son autorisation.
In compliance with the Canadian

Privacy Act some supporting forms may have been removed from this thesis.

While these forms may be included in the document page count, their removal does not represent any loss of content from the thesis.
Conformément à la loi canadienne sur la protection de la vie privée, quelques formulaires secondaires ont été enlevés de cette thèse.

Bien que ces formulaires aient inclus dans la pagination, il n'y aura aucun contenu manquant.

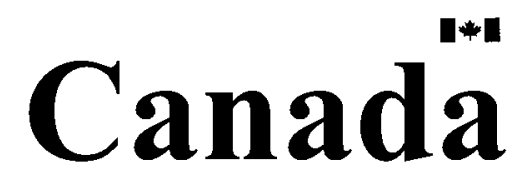




\begin{abstract}
This thesis analyzes China's attitude to antidumping law, competition law, and a possible international competition law. The process of exploring China's attitude to these laws raises a theoretical basis for what constitutes law. In order to narrow the gap between law on the books and law in real life, to practice beneficial laws, and to effectively implement laws, this thesis is rooted in the sociology of law with a focus on the Constitutive theory, especially its society-first departure point, to make law necessary, natural, and rational.

By researching developed and developing countries' social conditions and needs, and their dissimilar views on the necessity or not of these laws, and their objectives, contents and enforcements, this thesis draws a conclusion that different social conditions and requirements will lead to different attitudes to law. To predict China's opinion on these laws, it is necessary to follow the Constitutive theory that underlines the society-first approach by clarifying China's external surroundings and its domestic economic, social and political features and requirements.
\end{abstract}




\section{Acknowledgements}

I would like to express my sincere gratitude to Professor Paul Davidson for the time and effort devoted to this thesis.

I would like to thank Professors Obijiofor Aginam and Christopher Penny, and graduate program administrator Andrew Squires for all of their suggestions and assistance.

And I must greatly appreciate my parents' encouragement and love. 


\section{Table of Contents}

\section{Introduction}

\section{Part I: The Constitutive theory}

\section{Part II: Antidumping Law}

1. Reasons for replacing antidumping law with competition law

1.1 The abuse of antidumping law - observations on U.S. and EU antidumping investigations

1.2 The gap between the original purpose of the Agreement and its real practice

1.3 The confusion of standards between antidumping law and competition law, and the rareness of predatory pricing

2. Predicting developing countries' perspective on the proposal about replacing antidumping law with competition law

3. Reforms of antidumping law

\section{Part III: Competition Law}

1. The definition of competition law and its objectives

2. Reasons for putting competition law into practice in developing countries

\subsection{The domestic pressures}

2.2 The international and external impacts and pressures

3. Reasons for resisting the practice of competition law in developing countries

3.1 A risk of competition law: competitiveness

3.2 Multiple objectives

3.3 Powerful state-owned enterprises

3.4 Detriments from too much competition

3.5 Lack of competition culture

3.6 No obvious relationship between competition law and competition

3.7 Lack of affirmative relationship between competition law and economic growth

4. Anti-monopoly law's history in Japan

5. An Egyptian approach-----distinguishing competition law from competition policy

\section{Part IV: A possible International Competition Law}

1. Developed countries' perspective: the necessity of competition policy in the World Trade Organization 
1.1 Limitations of the current competition-related provisions in the GATT and GATS

1.2Developing countries will gain from a multilateral competition agreement

1.3Problems arising from enforcement

2. The EU's Proposal for an international competition framework

3. The WGITC/WGTCP's recommendations

4. Developing countries' perspective: continuing clarification of the objectives, main principles and concepts of an international competition law is better than the start of negotiations

4.1 Developing countries' comprehension of an international competition law

4.2Developing countries' comments on the EU's proposal and the WGITCNGTCP's recommendations

\section{Part V: The application of the Constitutive theory}

1. Developed vs. Developing countries' views

2. China's attitude to antidumping law, competition law and a possible international competition law

2.1China's attitude to antidumping law

2.2 China's attitude to competition law

2.2.1 Reasons for lack of a comprehensive antimonopoly law

2.2.2 Chinese economic, social and political features

2.2.3 China's attitude to competition law

2.3 China's attitude to a possible international competition law

\section{Conclusion}




\section{Antidumping Law and Competition \\ Law---China's Position? \\ Introduction}

In today's international trade, China has become the favorite target of other countries for the practice of antidumping investigations. These investigations are resulting in more and more dramatically negative effects on China. Based on research of the real practice of United States and European antidumping laws, methods of determining and measuring dumping are biased in favor of finding dumping and establishing large dumping margins. in substance, in the real practice of antidumping laws, through a set of biased measures, antidumping actions have gone against their initial purpose and become the preferred means to impose restrictions on international trade and to protect domestic producers' interests from foreign competition. They are perceived as "measures (that) are being virtually used as weapons by certain developed countries to deny access to the products of developing countries". ${ }^{1}$

Faced with the abuse of antidumping law, to ensure that the international market is competitive, a Canadian proposal ${ }^{2}$ suggests replacing antidumping law with antitrust law ${ }^{3}$ since 1) antitrust law has a similar effect as antidumping

\footnotetext{
1 Inge Nora Neufeld, Antidumping and Countervailing Process ---Use or Abuse implications for developing countries, (New York: United Nations, 2001) at 16.

2 Derek J. Ireland, “Antidumping and Competition Policy Rules", Competition Bureau, available online: $<$ http://www.competitionbureau.gc.ca/internet/index.cfm?itemID $=1073 \& \mathrm{lg}=\mathrm{e}>$. Or see "Competition policy as a dimension of economic policy: a comparative perspective", Industry Canada, available online: <http://strategis.ic.gc.ca/epic/internet/ineas-aes.nsf/vwapj/op07e.pdf/\$FILE/op07e.pdf>. "Canadian Federation of Agriculture Trade Policy Statement: Introduction", Chicken Farmers of Canada, available online: <http://www.chicken.ca/DefaultSite/index_e.aspx?DetailID=97>.

3 The terms Antitrust law, Anti-monopoly law and Competition law have been developed in different jurisdictions to deal with the same subject matter, and are used interchangeably in this paper.
} 
law's original purpose on competition, and 2) the replacement can deal with the misuse of antidumping law in real practice, namely abuse in protecting domestic producers' interests from both fair and unfair competition or both real and unreal dumping.

Moreover, in order to remove internal and external barriers to trade, advanced economies, especially the EU, are seeking to set up a multilateral competition law. If an international competition law is agreed to, it will be unavoidable for China to establish its own competition law identical with the objective and content of the international competition law. Thus, it is necessary for China to comprehend whether there is a match between the objective and content of the possible international competition law and its own interests.

This thesis examines the approach that China may take to its antidumping law, competition law, and a possible international competition law. It focuses specifically on issues of antidumping investigations and the practice of competition law as well as the necessity of a possible multilateral competition law. The thesis is organized as follows.

First, in Part I, this thesis will focus on the Constitutive theory ${ }^{4}$ to present a basis for the enactment and development of law. The Constitutive theory underlines that the relationship between law and society is mutual. A law is constitutive in a society and is constituted by a society. A law's rationality and efficiency is dependent on its social necessity. Different social requirements

\footnotetext{
${ }^{4}$ Austin Sarat, "Discussion: Pain, Powerlessness, and the Promises of Interdisciplinary Legal Scholarship: An Idiosyncratic, Autobiographical Account of Conflict and Continuity" (2000) 18 Windsor Y.B. Access Just., at 192.
} 
will result in various countries' different opinion on a law's purposes and contents. On the basis of the Constitutive theory, especially adopting society-first, not law-first, ${ }^{5}$ as the point of departure of the Constitutive theory, this thesis will probe into the necessity or not of antidumping law, competition law and a possible international competition law from the perspective of developed and developing countries.

Second, Parts II, III, IV and V, as the main parts of this thesis, will successively explore antidumping law, ${ }^{6}$ competition law, ${ }^{7}$ a possible multilateral competition law and China's attitude to these laws. The aim of Parts II, III and IV is to provide a background or a basis for China to determine its approach to antidumping law, competition law and a possible international competition law by underlining that the necessity or not of these laws, and their objectives, contents and enforcements are dependent on every economy's own social conditions and needs. To predict China's attitude to these laws, according to the Constitutive theory, it is necessary to locate China's economic, social and political characteristics to disclose its social requirements.

Part II will explore the relationship between antidumping law and competition law by reviewing issues raised by antidumping investigations and the reasons for replacing antidumping law with competition law, and argue developing countries' approaches on dealing with the misuse of antidumping

\footnotetext{
5 The meaning of society-first and law-first will be discussed in Part $\mathrm{I}$.

${ }^{6}$ Antidumping law is aimed to counteract the practice of exporting goods at less than their normal value, causing or threatening to cause injury to domestic industries in the importing countries. More detailed definition will be given in section 1.3 of Part II.

Competition law can be defined as sets of rules that govern the way in which business firms compete or interact with one another in the markel place. More detailed definition is in section 1 of Part III.
} 
laws by developed countries. This part will demonstrate that the essential reason for the gap between the original purpose of antidumping law and its real practice is the disconnection between the law and the real social needs. Countries' opinion on antidumping law and its reforms will ultimately be determined by their own social necessity.

Part III will demonstrate that the different viewpoint on competition law between developing and developed countries results from different social requirements as well. Sections 1,2 and 3 will show the dissimilar opinion held by developed countries and developing countries on the necessity, the objective and the content of competition law. The basic cause for the difference is that developed and developing economies have a different comprehension of competition law that ties to diverse social necessity. Developed economies hold that the practice of competition law will increase competition and economic development, while developing countries argue that competition law should only be used if it increases economic promotion. The fundamental point for developing countries is whether there is a positive relationship between competition law and economic development. In other words, developed countries pay attention to the promotion of competition; however, developing states focus on seeking preconditions for economic development. If the implementation of competition law is a prerequisite for the long-term economic development, developing countries will practice competition laws. To examine the relationship between competition law and 
economic development, and to seek answers on whether it is necessary for developing countries to set up competition laws, and what constitutes appropriate competition laws for them, section 4 will review the historical experience of Japan with its Anti-Monopoly Act since Japan showed a significant shift in its attitude on the implementation of competition law.

Part IV argues that the fundamental root for the diverse attitude to a possible international competition law between developing and developed countries is dissimilar social conditions between them. Section 1 will examine reasons, pointed out by developed economies, for the necessity of setting up an international competition law. Sections 2 and 3 will state the outlined objectives, principles and contents of a possible international competition law, namely, the EU's proposal and the Working Group on the Interaction between Trade and Competition Policy's (WGITC/WGTCP) recommendations. Section 4 will emphasize developing states' perspective on the possible multilateral competition law. The analyses of this part underline that developing and developed countries definitely have a different understanding on a possible international competition law. From developing countries' perspective, an international competition law should focus on curbing mega-mergers and restricting business practices of foreign multinationals, such as price-fixing or bid rigging that lead to higher prices of imported products or services, and should not impact their flexibilities on policies that can support their industries or shield their industries from too much foreign competition. From developed 
countries' opinion, the substance of an international competition law is to maintain and develop international competition and to restrict economies' trade protection by entitling the same sets of rights between the host and foreign enterprises.

Part $\mathrm{V}$ links the previous parts by considering developments through the lens of the Constitutive theory. Section 1 explains that the main reason for most developed economies and developing countries to have the same approach to antidumping law is that almost every country uses antidumping law to protect its industries. As for competition law, a factor to restrict private firms' anti-competitive activities, and to deal with the abuse of antidumping law by replacing antidumping law, developed and developing economies have different standpoints on it, and even a possible multilateral competition law. Section 1 also shows that the essential cause for developed and developing countries to have diverse views on competition law and a possible international competition law is the different economic and social requirements between them. This section highlights the importance of society to law by applying the Constitutive theory. For a law to be legitimate and effective, it has to reveal the conditions of a society, such as culture, economic, political and social factors, that give shape and content to the law. Ignoring the facts of social life is foolish. Similarly, to locate China's attitude to antidumping law, competition law and a possible international competition law, it is necessary to clarify its economic, political and social requirements. It is rational to seek the 
answers from the Constitutive theory. Section 2 successively explores the opinion of China to its antidumping law, competition law and a possible multilateral competition law by utilizing the Constitutive theory and researching China's external surroundings and its domestic economic, social and political features and requirements. 


\section{Part I}

\section{The Constitutive theory}

Because this thesis analyzes China's attitude to antidumping law, competition law, and a possible international competition law, it is necessary to explore the theoretical basis for the role of law in society. The process of exploring China's attitude to these laws raises the question of what constitutes law as well as how law is to be defined. This thesis is rooted in law and society school with a focus on the Constitutive theory.

In the sociology of law, there are two basic approaches, namely, the Instrumental and the Constitutive. The two approaches have four significantly different characteristics. First, the Instrumental approach resolutely separates a law from a society, and sees a law as a tool for sustaining or changing aspects of social life; while, the Constitutive theory insists that a law is part of a society.

Second, the Instrumental theory stresses that the impacts of law on society are through "imposing external sanctions and inducements". ${ }^{\circ}$ On the other hand, the Constitutive theory contends that the effects of law are seen in meanings and self-understanding rather than the threat of adjudication or the coercion by the state that routinely induce people to perform those duties. ${ }^{9}$ In other words, people who live in a society are not just "the inert recipients of

\footnotetext{
8 Austin Sarat \& Thomas R. Kearns, "Beyond the Great Divide: Forms of Legal Scholarship and Everyday Life", in Austin Sarat \& Thomas R. Kearns eds., Law in Everyday Life, (The University of Michigan University Press: Ann Arbor, 1993) at 21, 23 \& 51.

${ }^{9}$ Ibid. at 23 \& 51.
} 
law's external pressures". ${ }^{10}$ Rather, the people imbibe "law's images and meanings"11 to make them seem the people. As a consequence, demands of law look "natural and necessary, hardly like demands at all". ${ }^{12}$

Third, as for the influence of law on society, the Constitutive approach pays more attention to law's effects than does the Instrumental approach. ${ }^{13}$ The Constitutive theory underlines that law has authoritative power on a society. William Douglas states, "the private sphere, the world of the everyday, has already been penetrated and partially constituted by the very legal notions that required filling in". ${ }^{14}$ For example, "agents" of a corporation are legal creations, rather than sources for legal reasoning and judicial decisions. ${ }^{15} \mathrm{~A}$ social scholar supporting the Constitutive theory, Barbara Yngvesson, claims, "law creates the social world by 'naming' it; legal professionals are empowered by their capacity to reveal rights and define trouble, as private nuisance or public grievance, and thus to shape culture understandings of fairness, of justice, and of morality". ${ }^{16}$ Barbara Yngvesson considers that the influence of law on society is hegemonic, beyond constitutive. Law creates and shapes a society to be the one that it wants.

Fourthly, the Instrumental theory considers that the relationship between law and society is unilateral since it puts weight on the influence of law on

\footnotetext{
10 Ibid. at 29.

11 Ibid.

12 Ibid.

13 The Instrumental theory is interested in law's effectiveness, not in law's effects more broadly conceived. See Austin Sarat \& Thomas R. Kearns, Supra note 8, at 23.

14 Austin Sarat \& Thomas R. Kearns, Supra note 8 , at 39

15 Ibid.

16. Austin Sarat, Supra note 4 , at 194.
} 
society, not touching the impacts of society on law. The Constitutive theory, however, asserts that the relationship between law and society is mutual. For instance, Barbara Yngvesson emphasizes, "hegemony assumes plurality: it does not just passively exist as a form of dominance. It has continually to be renewed, recreated, defended, and modified. It is also continually resisted, limited, altered, challenged by pressures not at all its own". ${ }^{17}$ In Yngvesson's opinion, legal meaning is not only invented and communicated in a "unidirectional process" since meaning and the materiality of law, produced in concrete and particular social relations, cannot separate from each other. A law is "moving hegemony". 18

Comparing the two essential approaches, we can draw conclusions that although both theories concern the influence of law on society, the methods of impact are different. The Instrumental theory underlines that a law, standing outside of a society, affects the society by external sanctions and inducements. On the contrary, the Constitutive theory considers that a law, a piece of a society, shapes the society by "internal meanings and creating statutes". ${ }^{19}$ Also, the Constitutive theory underlines that the influence of law on society is authoritative and even hegemonic, not just general effectiveness, like the Instrumental theory, and a law could not be understood apart from its social context. The Constitutive theory reveals that the relationship between law and

\footnotetext{
17 Barbara Yngvesson, "Inventing Law in Local Settings: Rethink Popular Legal Culture" (1989) 98 Yale L. J., at 1693.

18 Ibid.

19 Austin Sarat \& Thomas R. Kearns. Supra note 8, at 21.
} 
society is reciprocal, and underscores both the importance of law to society and the importance of society to law.

Based on the comparisons between the Instrumental and the Constitutive theory, this thesis prefers the Constitutive theory to the Instrumental approach because of the characteristics of the Constitutive theory. The Constitutive theory pays attention to the existence of law as part of a society, and the practice of law as natural and internal. The relationship between law and society is reciprocal, not unilateral. These traits can diminish and even avoid the gap between law on the books and law in real life, and increase law's rationality and effective enforcement.

Because of the reciprocal relationship between law and society, there are two points of departure for the law and society school, namely law-first and society-first. This thesis prefers society-first as the departure point since society-first, rather than law-first, could be a more genuine approach of sociologic jurisprudence studies. ${ }^{20}$ As explained by Barbara Yngvesson, law is continuously constituted and reconstituted by the ways it is used. Putting law as the starting point or adopting law-first can overlook much of the richness and complexity of the interaction between law and society. To advance a more enlightened, rational, and efficient law, it is necessary to set up a law due to its natural and internal necessity. Thus, it is better to take society as the departure point, to research normative resources of a society, especially its social,

\footnotetext{
20) Ibid. at 54-61.
} 
economic, political and cultural phenomena, and to locate authentically social conditions and requirements in order to make laws become natural and internal.

Focusing on the Constitutive theory, especially its trait on highlighting the importance of society to law, this thesis adopts society-first as the departure point. ${ }^{21}$ It draws a conclusion that different social conditions and requirements will lead to different attitudes to a law by researching developed and developing countries' social conditions and needs, and their dissimilar approaches to antidumping law, competition law and a possible international competition law. There is no exception for China. To narrow a gap between a law's practice in the real world and its exacted provisions and regulations, and to effectively implement a law, it is necessary to make the law necessary, natural, and rational. It is argued that China should follow the Constitutive theory that underlines the society-first approach by highlighting China's social circumstance and requirements.

\footnotetext{
${ }^{21}$ Developed countries' support for setting up competition laws in developing countries and even a multilateral competition framework in the WTO, and developing economies' hesitation on the practice of competition law and the rejection of a proposal for an possible international competition law imply the importance of law to society and its constitutive and even hegemonic role in a society. It could reflect the law-first departure point of the Constitutive theory. For example, developed states' enterprises will get significant benefits, while, at the same time, developing countries' firms will lose dramatically through the market access power resulting from the practice of the non-discrimination principle of the possible international competition law.
} 


\section{Part II}

\section{Antidumping Law}

As stated in the introduction, antidumping law has been abused to impose restrictions on international trade and to protect domestic producers' interests from foreign competition. Faced with the gap between its real practice and its original purpose, namely stimulating international competition by militating against private firms' unfair activities, it is necessary to ask why and how the law turns out the way it has. To deal with the misuse of antidumping law, the Canadian proposal has been made that antidumping law be replaced with competition law. To determine the rationality and practicality of the Canadian proposal, it is necessary to comprehend the relationship between antidumping law and competition law.

In this part, section 1 explores the relationship between antidumping law and competition law by examining the reasons for the Canadian proposal, including causes and measures for the gap between the original objective of antidumping law and its real practice. Section 2 predicts developing countries' approach to the Canadian proposal. Section 3 examines developing economies' suggestions on reducing the abuse of antidumping law.

\section{Reasons for replacing antidumping law with competition law}

1.1 The abuse of antidumping law - observations on U.S. and EU antidumping investigations

\section{Costs}

Antidumping investigations are very expensive. In the case of antidumping actions in the U.S., there are costs for complying with the Commerce 
Department's requests for information and getting U.S. legal services. ${ }^{22}$ Also, the much higher cost of defending as compared to the cost for the domestic industry of filing such cases makes it more difficult for developing countries' exporters to defend their interests. ${ }^{23}$ Insufficient legal and financial resources limit the capacity of developing economies' exporters to argue the legitimacy and legality of antidumping actions.

\section{Duration}

Antidumping actions are supposed to be conducted speedily. However, in practice, they often take a long time, which aggravates negative impacts on developing countries. Although most countries try to complete their antidumping investigations within the maximum time limit foreseen in the WTO Agreement, ${ }^{24}$ some countries exceed the limit to conclude their procedures. For example, the European Union takes an average of 598 days to complete its antidumping investigations, which exceeds the WTO Agreement's maximum time limit by 58 days. Some antidumping actions take up to three years to complete. About 15 percent of all investigations initiated by the European Union terminate unfinished due to the expiry of the deadline to impose final measures. Over 90 percent of antidumping actions initiated by the United States last more than 5 years. ${ }^{25}$ The more time spent on antidumping

\footnotetext{
${ }^{22}$ Bruce Gregory Arnold, How the GATT affect(s) U.S. antidumping and Countervailing---Duty Policy, (The Congress of the United States: Washington D.C., 1994) at 52.

${ }^{23}$ Ibid.

24 "Agreement on Implementation of Article VI of the General Agreement on Tariffs and Trade 1994", Article 5.10 states that except in special circumstances, investigations shall be concluded within one year, and in no case more than 18 months, after their initiation.

${ }^{25}$ Inge Nora Neufeld, Supra note 1, at 7.
} 
investigations will lead to more financial burden on defendants, especially for developing countries, and more other negative impacts, such as the deterioration of the trade relationship between the applicant and the defendant.

\section{Cumulation}

The practice of cumulation involves assessing the effects on a domestic industry from all like imports from every country under investigation. Studies have shown that cumulations lead to a dramatically affirmative-finding bias in injury determination by antidumping authorities. ${ }^{26}$ For instance, based on the analyses done by Prusa, cumulation increases the possibilities of protection by about 30 percent. $^{27}$ An analysis of European Union cases ${ }^{28}$ shows that the implemention of cumulation raises the likelihood of affirmative findings by 42 percent. Without cumulation, the outcome would have changed from a positive to a negative injury finding in $\mathbf{3 6 . 5}$ percent of all cumulated cases.

More important, there are particular negative influences on countries with small import market shares. ${ }^{29}$ Enterprises that do not have sufficient export volumes to cause injury have antidumping duties imposed on them because of the use of cumulation. Also, cumulation leads to more multiple-country petitions by domestic industries, which are often directed against countries with small import market shares. ${ }^{30}$ All of these facts are particular to

26. Ibid.

27 Referred to by Inge Nora Neufeld. Supra note 1, at 7.

28 Inge Nora Neufeld, Supra note 1 , at 7 .

29 Ibid.

30 Ibid. 
developing countries due to their small import market shares.

\section{Duty levels}

Regarding limits on the size of antidumping duties, Article 9.3 of the Agreement on Implementation of Article VI of the GATT states, "the amount of the antidumping duty shall not exceed the margin of dumping". ${ }^{31}$ Article 9.1 points out, "it is desirable...that the duty be less than the margin if such lesser duty would be adequate to remove the injury to the domestic industry". ${ }^{32}$ However, in practice, the U.S. antidumping duty is always equal to the margin of dumping, even if less duty would be sufficient to remove any injury on the domestic industry. In other words, the measure of the imposed duty is not in accord with what the Agreement desires. According to Prusa (1999), antidumping duties are now an average 10 to 20 times higher than the most favored nation (MFN) level, with some of them exceeding the average MFN level more than 100 times. $^{33}$

\section{Target industries}

It has been observed that antidumping investigations are more often incurred for products for which tariffs have been dramatically lowered or even entirely removed. ${ }^{34}$ Investigations involving chemicals, cotton, polyester yarns and steel products are examples of this tendency. ${ }^{35}$ Also, in the case of textiles, the Phase-out of the Multifibre Agreement (MFA)-type of quantitative

\footnotetext{
31 "Agreement on Implementation of Article VI of the General Agreement on Tariffs and Trade 1994", the World Trade Organization, available online: $<$ http://www.wto.org/english/docs_e/legal_e/19-adp_02_e.htm\#articlelX>. 32 Ibid.

33 Referred to by Inge Nora Neufeld, Supra note 1, at 10.

34 Bruce Gregory Arnold, Supra note 22, at 10.

35 Inge Nora Neufeld, Supra note 1 , at 13.
} 
restriction results in an increase of antidumping investigations in these products. ${ }^{36}$ Antidumping investigations in these industries imply that the domestic authorities can still protect the producers' interests in these industries, though superficially following their obligations embedded in the WTO Agreement.

\section{Statutory minima for profit and administrative overhead}

According to the United State's antidumping law, when the import price is compared with the constructed value, and when there is inadequate home-market or third-country sales, the constructed value must, by law, include an amount for general, selling, and administrative costs of at least 10 percent and a profit margin of at least 8 percent. $^{37}$

Based on the statutory minimum percentages, the calculated value and profit will be larger than those of real value and profit. The statutory minimum percentages, which especially emphasize greater profits, artificially increase the possibilities of dumping being found. The statutory minima make the antidumping law become a more effective general source of protection. ${ }^{38}$

\section{"Best information available"}

To carry out antidumping investigations, the U.S. Commerce Department (DOC) needs data from firms being investigated about their costs and other relevant elements. Foreign firms are fearful of having antidumping duties imposed, thus they are reluctant to disclose information that may lead to duties.

\footnotetext{
${ }^{36}$ Ibid.

${ }^{37}$ Ibid.

${ }^{38} \mathrm{Ibid}$.
} 
The U.S. law and police power cannot force foreign firms to hand over the information, so the law provides that the DOC can use the "best information available"39 $^{39}$ BIA) when a foreign firm does not provide, or sufficiently provide, or provide in a specified manner needed information.

In practice, BIA is data supplied by the domestic industry petitioner and is often biased in favor of finding a large dumping margin to protect its interest. ${ }^{40}$ Although BIA is a fair method to encourage foreign firms to cooperate, enterprises, especially developing countries' firms, find that it is hard and expensive to provide the information that the DOC requires in the form that the department wants it and within the deadlines set by the DOC. ${ }^{41}$ Tracy Murray describes the plight of the investigated firms as follows:

Consider the problem facing the foreign respondent who receives a request for information from the DOC. It arrives in the form of a questionnaire, some 100 pages long, in English, requesting specific accounting data on individual sales to the United States, data needed to adjust arm's length market prices to net ex-factory prices (that is, packaging costs, shipping costs, selling costs, distributor and other middleman costs, tariffs in the United States, distribution costs in the United States, and any costs of adding value in the United States), and a host of other details (especially if the foreign market value needs to be constructed). There must be enough information for the DOC to investigate nearly every U.S. sale, (that is, every transaction) for a period of six months. All this information must be identified, retrieved, recorded, and then transmitted to the DOC in English on hard copy and in a computer-readable format within the short deadline stipulated under the U.S. antidumping statutes. ${ }^{42}$

${ }^{39}$ Bruce Gregory Arnold, Supra note 22, at 37.

4) Ibid.

41 Ibid.

42 Referred to by Bruce Gregory Arnold, Supra note 22, at 38. 
Usually, the first part of the required data must be made in 30 calendar days, sometimes within two weeks. ${ }^{43}$ Once a foreign firm fails to respond fast enough, the DOC will practice BIA that can bias the determination against the foreign firm.

On the contrary, the burden on domestic firms is considerably less. ${ }^{44}$ The Congress underlines that the DOC and the International Trade Commission (ITC) should assist domestic firms to file petitions for antidumping. Also, the Trade and Tariff Act of 1984 states that agencies, which administer the antidumping law, should give technical assistance to small firms desiring to file petitions for relief. The amount of data required of domestic firms is smaller than the requests of foreign firms, and the ITC does not need the data in computer-readable format due to the burden that would place on small domestic firms.

\section{Measures for non-market economies}

The biases in locating dumping and enlarging dumping margins are much worse in cases involving non-market economies. In non-market economies, since the market is not the only factor to determine the prices of goods, and since the costs of producing products in non-market economies cannot be calculated by adding up various inputs multiplied by their respective prices, the DOC locates another market economy's prices and adds up those calculated

43 Bruce Gregory Arnold, Supra note 22, at 38.

${ }^{44}$ Ibid. 
inputs' costs to obtain the total costs. ${ }^{45}$

Although the DOC selects a third country with a similar level of development and similar resources to calculate the so-called actual non-market products' costs, the procedure is not very accurate. For example, different countries have different tariff structures, which can result in the prices of various goods differing in ways that are too complicated to sort out without detailed models of the economies. Different countries have different cultures that can lead to different patterns of consumption and production, which in turn result in different prices. In short, countries will have significantly different prices of products though having certain similarities; therefore, the procedure of choosing a similar market could be a device for determining dumping for goods from non-market economies. ${ }^{46}$ In addition, it is subjective to choose the most similar country. The subjectivity leaves possibilities for the DOC to choose a country that would lead to a dumping margin. ${ }^{47}$

The EU follows a similar practice. Since the EU's institutions put China as a non-market economy, they select an analogous country to determine the normal value of goods from China. This measure makes it easy for the EU's institutions to find artificially high dumping margins for Chinese products. For example, in the Furazolidone case ${ }^{48}$ India was selected as the analogous country. The domestic price in India was higher than the EU's market price

\footnotetext{
45 Ibid. at 40.

46 Ibid.

47 Ibid.

48 Donghui Fu, "EC Antidumping Law and individual Treatment Policy in Cases involving Imports from China" (1997) 3I(1) Journal of World Trade, at 79-80.
} 
because the Indian market was highly protected by the application of a very high customs duty of 100 percent. This selection enabled the institutions of the EU to find dumping of Chinese goods and a large dumping margin. The system of selecting an analogous country has been described "as equivalent to charging a driver for speeding on a road with no speed limits, based upon the limits posted on some other road---a road that would be chosen only after the driver has been stopped by the police". 49

\section{Defined industry}

How an industry is defined is important to determine whether dumped imports cause material injury. Import competition can substantially impact narrowly defined parts of an industry, while the whole industry is still healthy and uninjured. ${ }^{50}$ In other words, if an industry is narrowed to only parts, the ITC is much more likely to find that the import leads to material injury. For instance, in the case of fresh cut flowers, ${ }^{51}$ when the whole flower industry was at issue, usually the ITC did not find injury. However, when specific flowers were questioned, the ITC did locate injury.

\section{Measures used for deciding injury}

Do the ITC commissioners make their decisions only on factors indicating injury on an industry caused by dumped imports? Are other elements also involved in their decisions? A study ${ }^{52}$ analyzes that there are 17 different

\footnotetext{
49 Ibid. at 80 .

so Bruce Gregory Arnold, Supra note 22, at 40.

51 Ibid.

52 Ibid. at 53.
} 
variables used by the ITC to decide injury. In the 17 variables, there are five variables that commissioners might consider relevant to decide whether an industry is injured by dumped imports---"change in production, change in production employment, change in profit-to-sale ratio, change in volume of dumped imports, and the dumping margin". The other 12 variables are not related to the injury by dumped imports ${ }^{53}$. In other words, irrelevant factors are involved in determining whether there is injury and its intensity.

\section{Discrimination policies}

In 1993, the EU's institutions implemented a retrogressive policy by systematically refusing to grant individual treatment on Chinese exporters and other non-market economies (NMEs). This means that a dumping margin is calculated based on a comparison between the average prices charged by all exports of like products from China. The EU can apply a single countrywide duty to all Chinese exporters. A Chinese exporter who does not practice dumping will be imposed an antidumping duty if other Chinese enterprises are dumping their products. ${ }^{54}$ The refusal to give individual treatment to Chinese products is a discriminatory policy against China by encouraging exclusion of Chinese products from the EU's market.

\footnotetext{
${ }^{53}$ Ibid. The 12 other variables are $1>$ changes in volume of all imports (not just dumped imports), $2>$ the wage rate, $3>$ whether the imports in question come from a developing country, $4>$ whether the imports come from a newly industrialized country (NIC), $5>$ changes in employment for the four-digit Standard Industrial Classification (SIC) category that includes the industry in question (a broader classification than the industry itself), $6>$ the national unemployment rate, $7>$ the profit-1o-sales ratio, $8>$ whether the imports come from Japan, $9>$ whether the imports come from a member country of the OECD, 10> the number of workers in the four-digit SIC category that contains the industry, $\mathrm{ll}>$ whether the industry contains a manufacturing plant in a state represented by a member of the Senate trade subcommittee, and $12>$ whether the industry contains a manufacturing plant in a Congressional district represented by a member of the House trade subcommittee.

${ }_{54}$ Donghui Fu, Supra note 48, at 73-74.
} 
Also, the EU's institutions apply other discriminatory practices. For instance, in the Furfuraldehyde case ${ }^{55}$ although the export price from the Dominican Republic was 40 percent lower than that of China, and its export volume to the EU was 400 percent higher than that of China, the institutions of the EU decided that the injury suffered by the EU industry was not caused by imports from the Dominican Republic, but by imports from China only.

\section{Effects on trade flows}

Regardless of whether a duty will be imposed, antidumping investigations can have negative effects on trade flows, especially inducing drops in exports. Before the imposition of duties, due to huge costs, uncertainties, and fear of the future retroactive imposition of a duty, ${ }^{56}$ foreign exporters often agree to export restraints, even if they are not really dumping. A study shows that 45 percent of examined cases were finished in negotiated export restraints, with prices increasing by more than 30 percent during the same period..$^{57}$

\subsection{The gap between the original purpose of the Agreement and its real practice}

Based on the above observations, we can draw conclusions that antidumping laws are biased in favor of finding dumping and larger dumping margins. More important, there is a gap between the original purpose of antidumping law and its real practice. Antidumping actions are not only against predatory pricing causing unfair competition, but are abused for protecting

\footnotetext{
ss Ibid. at 81 .

56 Article 10.8 of the WTO Agreement on Implementation of Article VI of GATT allows the retroactive imposition of a duty from the date of initiation of the investigation. To avoid the possibility of duties being levied retroactively, exporting countries have to reduce the amount of exports to diminish the likejihood of dumping and dumping margins.

57 Bruce Gregory Arnold, Supra note 22, at 52.
} 
domestic producers' interests from both fair and unfair competition or both real and unreal dumping.

\subsection{The confusion of standards between antidumping law and competition law, and the rareness of predatory pricing}

As defined in Article VI of GATT, dumping is exporting goods at less than their normal value, causing or threatening to cause injury to domestic industries in the importing countries. Normal value is defined as 1) the domestic price in the exporting country, or 2) if such price is not available, either as a) the price of exports to third states or b) a constructed value based on costs. ${ }^{58}$

Private firms' activities that are treated as unfair based on the criteria of antidumping law could be fair according to competition standards. For example, in the real practice of international trade, it is common to sell identical goods for different prices in different markets since, in the field of marketing, it is commonly accepted that firms determine optimal prices for each market based on the function of demand and supply. ${ }^{59}$ When the function of demand and supply in the importing country is different from that of the exporting country or third states, it is reasonable for producers to put a different price in different markets for identical goods. It is not anti-competitive, unless the price involves some form of below-cost pricing for predatory purposes, such as driving out competitors and subsequently charging a monopoly price. ${ }^{60}$

\footnotetext{
58 "Agreement on implementation of Article VI of the General Agreement on Tariffs and Trade 1994", the World Trade Organization, available online: <http://www.wto.org/english/docs_e/legal_e/19-adp_01_e.htm>.

59 Gunnar Niels \& Adriaan ten Kate, “Trusting Antitrust to Dump Antidumping: Abolishing Antidumping in Free Trade Agreements without Replacing it with Competition Law" (1997) 31(6) Journal of World Trade, at $29-43$.

60 Ibid. at 36
} 
Moreover, there is confusion in the criteria used for antidumping law and competition law. Due to low competitiveness, it is possible for producers to suffer sets of injury, such as declining market shares, increasing imports, shrinking profit margins and even going out of business. These phenomena of injury in the process of competition are also the typical phenomena in antidumping cases. ${ }^{61}$ Thus, it is difficult to determine the reason for injury. It is hard to state that injury in antidumping cases results from dumping, not from weak comparative advantage, low international competitiveness or other factors.

If upholding the objective of antidumping law is stimulating international competition by opposing private firms' unfair activities, the practice of antidumping law should limit its investigations to the area of predatory pricing only, due to its unfair nature, which drives competitors out of the market and afterward charges monopoly prices to gain higher profits. However, in reality, the process is abused to protect domestic producers' interests from both fair and unfair competition or both real and unreal dumping.

To distinguish legitimate price competition from predation, there is a consensus among competition authorities that the alleged predator must have market power in order to succeed. ${ }^{62}$ Without a substantially large share, a predatory strategy would take too much time and imply huge losses. In international trade, it is rare for an alleged dumper to have sufficient market

61 Ibid. at 34.

62 Ibid. at 35 . 
shares to force out all producers in the importing countries and other exporting countries; a firm will find that it is hard to increase prices to monopoly levels afterwards, even if it is successful in driving out the competitors of the importing countries. ${ }^{63}$

\section{Predicting developing countries' perspective on the proposal about replacing antidumping law with competition law}

Sections 1.1 and 1.2 of this part emphasize that although the original purpose of antidumping law is to prevent unfair competition caused by practicing predatory pricing, in practice, antidumping law has been misused to protect domestic producers' interests. Section 1.3 focuses on the confusion in the application of the criteria used for antidumping law and competition law. To deal with the abuse of antidumping law in real practice, to focus on unfair competition activities only, to maintain and promote a competitive international market, a Canadian proposal suggests replacing antidumping law with competition law.

In order to assess the Canadian proposal, it is first necessary to ask whether it is reasonable to give up antidumping law. This requires questioning whether antidumping law is not good per se. Consumers get gains from dumped products while domestic producers of the like products can suffer losses. There is a conflict between the short-term benefits to consumers' buying dumped products and the long-term national economic interests, especially for domestic producers' interests, therefore, it is hard to say whether

\footnotetext{
63 Ibid. at 37 .
} 
dumping is not good per se.

In addition, antidumping actions may lead to damages on downstream users. For example, in the unbleached cotton fabrics case between the EU and the defendants, namely, China, India, Indonesia, Pakistan and Turkey, ${ }^{64}$ antidumping helped to save some sixty thousand jobs in the weaving industry; however, it dramatically prejudiced several hundreds of thousands of jobs in the downstream industries, such as dyers, printers and the making-up sector. In short, on the one hand, antidumping actions can lead to detriments; while, on the other hand, they can result in benefits. There are a number of conflicts; it is hard to decide whether antidumping is not good per se.

Secondly, based on the gap between the original objective of antidumping law and its real practice, it is necessary to think about why the antidumping law has turned out to be the way it is, and what the factors are to affect and even to shift its initial purpose. The main reason for the gap is the divergences between the competition purpose, which is largely concentrated in promoting competitive markets, and the trade purpose, which has objectives, besides promoting a competitive international market, of raising revenue, saving domestic workers' jobs, protecting domestic competitors from importing competitors, and maintaining stable price levels. ${ }^{65}$ The choice of countries' ultimate objective, namely, treating antidumping law as a kind of trade law for

\footnotetext{
${ }^{64}$ Edwin Vermulst \& Bart Driessen, "New Battle Lines in the Anti-Dumping War---Recent Movements on the European Front" (1997) 31(3) Journal of World Trade, at 155. Or see "Textiles and Clothing---Who Gains, Who Loses, and Why?" (1997) 5 Briefing Paper, CUTS International, available online: <http://www.cuts-international.org/1997-5.htm\#Anti-dumping\%20under\%20the>.

${ }^{65}$ Kevin Kennedy, Competition Law and the World Trade Organization: the Limits of Multilateralism, (Sweet \& Maxwell: London, 2001) at 5-11.
} 
safeguards, or as a competition law for maintaining and developing competition, will determine whether there is a gap, and the choice is rooted in every country's own society. Specifically, if a country, based on its social necessity, puts antidumping law as a kind of trade law for protection rather than a competition law for promoting competition, a gap between the original purpose of antidumping law and its real practice will exist.

The observances, in the above section, have shown that developed countries treat antidumping laws as tools to shield their domestic producers from foreign competition whether fair or unfair. In other words, developed countries prefer to treat antidumping law as a kind of trade law for protection rather than a competition law for competition. Developing countries may conclude that they should practice their antidumping laws for the same protection purpose.

In practice, the application of antidumping procedures has spread from a few traditional developed nations, (the United States, the European Union, Canada and Australia) to developing countries, such as Argentina, Brazil, India, the Republic of Korea, Mexico and South Africa. ${ }^{66}$ Since 1995, developing countries have accounted for 60 percent of all investigations. Specifically, China, the favorite target of other countries, is also the tenth most active user of antidumping law. ${ }^{67}$ Developing countries are also often the targets of investigations initiated by their fellow developing countries; and developing

\footnotetext{
${ }^{66}$ Inge Nora Neufeld, Supra note 1, at 4-5.

${ }^{67}$ Linda M. Young \& John Wainio, "The Antidumping Negotiations: Proposals, Positions and Antidumping Profiles" (2005) 6(1) Journal of International Law and Trade Policy, at 23-46.
} 
counties are more likely to impose antidumping duties against developing countries. ${ }^{68}$ What is the motivation for the increased use of antidumping law by developing countries? Is it for retaliation or for relieving the pain from opening their domestic markets? The increased number of developing economies practicing antidumping laws may imply that developing countries favor using antidumping laws as weapons for relieving pains from foreign access to their national markets and protection rather than competition. Since developed countries prefer protection by their antidumping laws, it should not be surprising for developing states to use their antidumping laws as a shield as well.

Thirdly, the divergences between competition law and trade law also can be seen as the conflicts between competition interests and other social requirements' interests. One of the most important conflicts is the clash between competition interest and industrial interest. The conflict between them is essentially a conflict of priority. The supporters of liberal world trade treat competition law as the best precondition for economic growth and welfare development. The opponents think that as long as a domestic economy is too weak, it needs to be supported by state measures, to be protected against international competition and to have the industries' competition abilities increased at the international level. ${ }^{69}$ Countries, especially developing countries, have to determine which policy should be given precedence, namely,

\footnotetext{
68 Inge Nora Neufeld, Supra note 1, at 16-17

${ }^{69}$ Kevin Kennedy, Supra note 65.
} 
"to institute, preserve, and safeguard a free market competition or to strengthen industries and specific industry sectors?"70

Developed states have put antidumping laws as common tools to protect domestic producers from foreign competition. Developing countries would regard antidumping law as a trade law for protection rather than treating it as a competition law as well because of the social priority on protection. In other words, developing countries resort to antidumping laws to avoid intense international competition, to protect their domestic producers' interests, to promote their industrial policies and to get long-term economic growth. From this perspective, it might not be wise for developing countries to regard antidumping law as a competition law and to replace it with competition law.

\section{Reforms of antidumping law}

Since developing countries would treat antidumping laws as tools to protect their economies rather than oppose unfair competition, or since they would regard antidumping laws as trade laws, but not competition laws, developing countries would not support giving up antidumping laws and replacing them with competition laws directly, but rather, would seek reforms in the current antidumping laws. For example, reviewing the issues observed in section 1.1 of this part would suggest the following reforms. ${ }^{71}$

First, to reduce the number of antidumping investigations, it is necessary

\footnotetext{
70 Wolfgang Fikentscher, "Collaborative Activities among Industrial Competitors---in German, European, and U.S. Antitrust law, and in the Draft International Antitrust Code in the GATT/WTO system", in Chia-Jui Cheng eds., International Harmonization of Competition Laws, (Martinus Nijhoff Publishers: Dordrecht, 1995) at 115-16.

${ }^{71}$ Inge Nora Neufeld, Supra note I, at 17-19.
} 
to prohibit the practice of cumulation. Second, the introduction of financial obstruction may reduce the number of antidumping actions as well. For example, petitioners may be required to bear the legal cost of defendants in cases in which the petitions turn out to be unjustified, or to deposit a guarantee, which will not be refunded if the investigations are not real dumping or do not result in injury. Third, to decrease the adverse effects of constructed value determination, it is required to restrict its implementation. Fourth, to reduce high dumping duties, it is necessary to limit the discretion of national authorities to impose duties up to the dumping margins. Fifth, to avoid the biases in favor of finding dumping, it is necessary to lower statutory minima for profit and administrative overhead and to avoid a set of discrimination policies and measures, such as the refusal of individual treatment.

Also, because of treating antidumping law as a kind of trade law to protect domestic producers' interests, it is better to focus on “acceptable versus (vs.) unacceptable levels of trade or market share or import penetration"72, rather than drawing the distinction of "fair" or unfair" trade. More important, to determine the appropriately acceptable level of "dumping" (not dumping for predatory purposes), it is necessary to put a "national economic interest" test or a "nation-wide cost-benefit analysis" into practice. ${ }^{73}$ National economic interest means "the sum of the benefits to all nationals who benefit minus the cost to all nationals who lose; injury, as it is defined in trade remedy law, is one

\footnotetext{
72 Raj Krishna, “Antidumping in Law and Practice”, the World Bank, 1997 at 10.

73 Ibid. at 13.
} 
half of the national economic interest". ${ }^{74}$ The relevance of this test is strongly advocated by Hoekman and Leidy. They state "incorporation of a national interest clause in antidumping procedures would be a major improvement. It would imply that before an affirmative finding can be made, a cost/benefit analysis should indicate that for the nation as a whole, protection of an industry is worthwhile". ${ }^{75}$ In short, to restrain excessive protection, it is necessary for antidumping authorities to shift their emphases from the effects on protected industries to the effects on the whole national economic interests. The implementation of the "national economic interest" test or the "nation-wide cost-benefit analysis" could be the best method for the evolution of antidumping law. It is not only a helpful way to determine "the acceptable level on trade or market share or import penetration", but also creates an equitable international competition level for developing countries, leaves room for developing countries to increase their international competition abilities in certain industries and to maintain their long-term economic development.

\footnotetext{
${ }^{74}$ Ibid.

${ }^{75}$ Referred to by Raj Krishna, Supra note 72, at 13.
} 


\section{Part III}

\section{Competition Law}

To evaluate the Canadian proposal of replacing antidumping law with competition law, it is necessary to analyze competition law to master the relationship between competition law and antidumping law. Competition law is also an important consideration in examining economic activity. In this regard, there are two different views on the essential reason for the Asian crisis in 1997-2000. One, such as that of U.S. policymakers Alan Greenspan and Larry Summers, holds that the basic reason for the crisis roots in too little competition in these countries, such as South Korea. ${ }^{76}$ The other one, such as that of scholars Jack Glen and Ajit Singh, however, considers that too much competition is the basic cause for the crisis. ${ }^{77}$ To fully comprehend the two diverse standpoints, it is necessary to further examine competition law.

Section 1 defines competition law and its varied objectives held by developed and developing countries. Section 2 explains developed states' viewpoint on the necessity of competition law in developing countries. Section 3 focuses reasons for resisting the practice of competition law from the perspective of developing economies. Section 4 reviews the history of Japan's competition law. Section 5 gives an overview of Egyptian competition law, which highlights the distinction between competition law and competition

\footnotetext{
${ }^{76}$ Jack Glen \& Ajit Singh, "Corporate Governance, Competition, and Finance: Re-thinking lessons from the Asian Crisis" Spring 2005 Eastern Economic Journal, at 6. Available online: $<$ http://www.findarticles.com/p/articles/mi_qa3620/is_200504/ai_nl4904760>.

${ }^{77}$ Ibid.
} 
policy.

\section{The definition of competition law and its objectives}

Competition law can be defined as sets of rules that govern the way in which business firms compete or interact with one another in the market place. ${ }^{78}$ Most countries believe that the common aim of competition law is to allocate resources more efficiently; however, its objectives may be seen differently by different countries. For example, according to the Model Law on Competition recently published by the United Nations Conference on Trade and Development (UNCTAD), the purposes of competition law are "to control or eliminate restrictive agreements or arrangements among enterprises, or merger and acquisitions or abuse of dominant positions of market power, which limit access to markets or otherwise unduly restrain competition, adversely affecting domestic or international trade or economic development" ${ }^{79}$ According to the Asia Pacific Economic Cooperation Council (APEC) which publishes a set of non-binding principles guiding the development of a competition-driven framework for APEC economies, "the ultimate goal of this competition framework is to promote the process of competition, as opposed to the welfare of individual competitors, in order to achieve greater overall economic efficiency and an increased average standard of living in domestic economies and the APEC region as a whole" ${ }^{80}$

\footnotetext{
${ }^{78}$ Ping LIN, "Competition Policy in East Asia: The Cases of Japan, People's Republic of China, and Hong Kong", the World Bank: Paper and Links, 2001. Available online: <http://rru.worldbank.org/PapersLinks/Developing-Competition-Policy>.

${ }^{79}$ Ibid.

${ }^{80}$ Ibid.
} 
Competition laws in some countries, such as Japan and P.R.China, also have consumer protection as one of the purposes of competition law. ${ }^{81}$

Generally, two models for the objectives of competition law are typically proposed. The first regards competition law as being solely focused on economic efficiency. The second regards the purpose of the law to maximize the "public interest". The public interest is usually defined as including economic efficiency, consumer welfare, a balanced development of the economy and perhaps maintaining employment, technical progress and exports. $^{82}$ In practice, since no economy only follows the rigid economic efficiency objective, the main difference between the two models lies between the law having multiple objectives or a single objective such as maintaining the efficient operation of markets. ${ }^{83}$ Faced with the two models, if developing countries enact their competition laws, which model would be more appropriate for them?

\section{Reasons for putting competition law into practice in developing countries}

\subsection{The domestic pressures}

Developing countries are moving towards privatization and deregulation to improve economic efficiency and competitiveness, and to deal with

\footnotetext{
${ }^{81}$ Until now, China lacks a comprehensive competition law. Currently the main laws and regulations in PRC that deal with competition issues are: the 1980 Regulations on Development and Protection of Competition, the 1993 Anti-Unfair Competition, and the 1998 Price Law. In the 1993 Anti-Unfair Competition, Article 1 states, "the objective of the law is to safeguard wholesome development of socialist market economy, to encourage and to protect fair competition, to curb unfair competition, and to protect rights and interests of businesses and consumers". See, "OECD Global Forum on Competition---the objectives of competition law and policy and the optimal design of a competition agency", Center for Co-operation with Non-members directorate for Finance, Fiscal and Enterprise Affairs, available online: <http://www.oecd.org/dataoecd/58/25/2485968.pdf>. Or see Ping LIN, Supra note 78, at $18-25$.

82 Tran Duc Minh, "Capacity---building for Post-Doha Pre-Negotiations: Regional Seminar on Competition Policy and Multilateral Negotiations", available online: <http://r0.unctad.org/en/subsites/cpolicy/gvaJuly/docs/enl 5.doc>. ${ }_{83}$ Ibid.
} 
organizational problems such as removal of enterprises from the political arena by reducing and even removing financial burdens to the state and putting the funds to socially beneficial projects such as health and education. ${ }^{84}$ The absence of competition law allows many state-owned enterprises that have monopoly power in the market to simply transfer from the public to the private sector. ${ }^{85}$ This transfer can harm consumers' interests, especially for the poor. For instance, large Korean enterprises use their market power at home to block rivals' entry to the market, to raise prices, and to resist the enactment and enforcement of competition law. Korea's experience reveals that to avoid monopolies getting excessive political and economic power to prevent opportunities for new entrants or to engage in excessive facility investments and price hikes resulting from inefficient operations, it might be important to put competition law into practice at the initial stage of economic development. ${ }^{86}$ In other words, competition law can help new entries, especially for small and medium firms, so that industries can grow on market-driven foundations, maintain a competitive market structure, ensure preconditions for fair competition, and build "a healthy industry platform".

\subsection{The international and external impacts and pressures}

In the international sphere, the present international merger movements

\footnotetext{
84 "The Economic and Political Case for Privatization", Enterprise Development Impact Assessment Information Service (EDIAIS), available online:

$<$ http://www.enterprise-impact.org.uk/word-files/Privatisation-2-Sectionl.doc>.

${ }^{85}$ Pradeep S. Mehta, "Competition Policy in Developing Countries: An Asia-Pacific Perspective", Bulletin on Asia-Pacific Perspectives 2002/03, available online: $<$ http://www.unescap.org/pdd/publications/bulletin2002/ch7.pdf> at 80 .

86 “Asian Development Outline 2005: III. Promoting competition for Long-term development”, Asian Development Bank, available online: <http://www.adb.org/Documents/Books/ADO/2005/part030300.asp>.
} 
point to the necessity of competition law. There are problems resulting from the increased market power of large multinationals and their potential abuse of dominance. The international mergers' monopoly power can directly affect a country when a foreign multinational acquires a domestic firm. ${ }^{87}$ There are also indirect effects on an economy as well, namely, international mergers can reduce the contestability of markets, which is especially harmful for certain developing countries' firms that are building up their capabilities to compete in the international market. ${ }^{88}$ In addition, international competition may result in an increasing unemployment rate in certain industries.

Many Asian countries lack internal interest in competition. The introduction of their competition laws results from external pressures or even direct interventions, not their domestic requirements. For instance, because of trade related pressures from the United States, enforcement of the Japanese 1947 Antimonopoly Act was remarkably improved during the 1990s. In Taiwan, after nearly a decade of deliberation and revisions, in 1991, the Fair Trade Law was implemented largely because of the external threat of trade retaliation from the U.S. The enactment of a new competition law in Indonesia was a direct consequence of an International Monetary Fund program designed to prevent the economy from ever falling into financial crisis like the one that occurred in $1998 .^{89}$

\footnotetext{
87 Ajit Singh, "Competition and Competition Policy in Emerging Markets: International and Developed Dimensions", the World Bank: Papers and Links, 2001. Available online: <http://rru.worldbank.org/PapersLinks/Developing-Competition-Policy> at 7-14. ${ }^{88}$ Ibid.

${ }^{89}$ Ping LIN, Supra note 78, at 33.
} 


\section{Reasons for resisting the practice of competition law in developing countries}

\subsection{A risk of competition law: competitiveness}

In international trade, compared with developed economies' industries, developing countries' industries are relatively small; do not have the same access to investment; and lack brand recognition or global marketing networks. Thus, in developing countries, competition law, by making it hard for domestic firms to coordinate their business policies and strategies, and difficult for national governments to practice industrial policy, is seen as reducing abilities of domestic enterprises to become internationally competitive..$^{90}$

There is no single accepted definition of industrial policy, but its persistent objective, in developing countries, is that industrial policy is aimed at promoting international competitiveness by facilitating structural transformations of their economies. ${ }^{91}$ As Ajit Singh (2002) states

the crucial importance of industrial policy is to achieve structural changes required for development. Likewise, structural change in favor of industry has been viewed as a prerequisite for developing countries' modernization and growth, and developing countries' industrial policies were aimed to speed up the industrialization process to achieve levels of industrial development that were comparable with those in Europe and North America. ${ }^{92}$

The ultimate objective of industrial policy is to hasten the national economic development through its intermediate objective, which is to expand output with high value added. ${ }^{93}$

Therefore, when there are conflicts between competition law and

\footnotetext{
90 Tran Duc Minh, Supra note 82.

91 Asian Development Bank, Supra note 86.

92 Ibid.

93 lbid.
} 
industrial policy, competition law should only be required as a subset of a nation's policies and should not be confused with other policies that affect the intensity of competition. ${ }^{94}$ Its scope and application should avoid dangers resulting from areas where it is not appropriate to focus on the pursuit of competition. ${ }^{95}$ Exclusions are necessary.

In short, for developing countries, risks could arise from the incorrect application of competition law. The objective of competition law is not confined to static efficiency, but is extended to dynamic economic performance. ${ }^{96}$ The governments regard competition laws as tools to attain their ultimate goal, namely, promoting national economic development, not only the pursuit of competition. In the case of young industries, to maintain dynamic efficiency and to compete efficiently in the world market, it is necessary for domestic firms to finance growth and limit rivalries. ${ }^{97}$

\subsection{Multiple objectives}

In practicing competition law, sets of opposite interests are inevitable for developing countries. For example, in the case of mergers in South Africa ${ }^{98}$, an anti-competitive merger may be permitted since it advances Black economic empowerment, which is advocated, while, a pro-competitive merger may be stopped because of its employment influence. When deciding whether to permit a merger, it is necessary for an agency to think about the effects of the

\footnotetext{
94 Ibid.

95 Tran Duc Minh, Supra note 82.

${ }^{96}$ Asian Development Bank, Supra note 86.

97 Ibid.

98 David Lewis, “Competition Regulation: The South African Experience”, Competition Tribunal, available online: $<$ http://www.comptrib.co.za/Publications/Speeches/Teipei\%20Conference\%20Speech.htm>.
} 
transaction, such as the impacts on employment and on advancing the ownership stakes of Black entrepreneurs. The agency has to evaluate and balance these conflicting ends. As for developing economies, distributional and poverty problems are the first order challenges. The existence and practice of competition law must have positive influence on dealing with the first order problems and other important social goals. ${ }^{99}$

\subsection{Powerful state-owned enterprises}

Although nowadays most developing countries are promoting the market economy and reducing government interferences, their governments still grapple with the legacy of powerful state-owned enterprises (SOEs) even though privatized. ${ }^{100}$ There are also powerful state interventions in key areas of economic life and distributional concerns either in the form of ownership or through the imposition of public service mandates on private enterprises. ${ }^{101}$

For instance, in South Africa, gigantic former SOEs are notable in transport, telecommunications, broadcasting, energy and armaments. These industries have either been privatized or part-privatized, or are in the process of major restructuring that will push them to privatization. However, some of these privatized SOEs' new shareholders have been granted specified periods of exclusivity in exchange for contractual commitments to meet specific public service mandates. ${ }^{102}$ When large parts of an economy, especially areas that

\footnotetext{
99 Ibid.

100 Ibid.

101 Ibid.

102 Ibid.
} 
have a powerful influence on economic development and consumers' interests, are excluded from the review of a competition act, the competition regime will be harshly discredited. ${ }^{103}$

\subsection{Detriments from too much competition}

To increase people's living standards over time, developing countries need high rates of investments to achieve fast growth of productivity. High rates of investments in turn normally require reasonable, if not high, rates of profits in order to maintain private sectors' investments. However, a high rate of investment will lead to excessive competition. Competition would be too much if it leads to price wars, sharp falls in profits, all of which are likely to diminish private sectors' desire to invest. ${ }^{104}$ In order to maintain an optimal rate of investment to stimulate economic development, it should be no surprise that governments intervene in investment decisions to prevent extreme competition.

\subsection{Lack of competition culture}

Lack of a healthy competition culture in developing countries, especially in the Asian and Pacific region, is an important reason for the poor performance of competition law. In these countries, firms that are better organized and financed are often against competition policies and laws, which directly affect their interests. For instance, in Thailand and Indonesia, there are strong pressures from business lobbies against the enforcement of competition laws.

103 Ibid.

104 Ajit Singh, Supra note 87 , at 4. 
In India, business lobbies have worked hard against a new competition law's enactment. ${ }^{105}$ Most consumers are also not aware of the relevance of competition law/policy. ${ }^{106}$

\subsection{No obvious relationship between competition law and competition}

An analysis, ${ }^{107}$ done by Glen, Lee and Singh, which examines the persistency of profits, the turnover (volume of business or of funds turnover), and the entry and the exit of firms, in seven emerging markets between the 1980s and the early 1990s, indicates that developing economies have consistently lower persistency coefficients than those observed for advanced countries, greater turnover, as well as more entry and exit of firms than those of advanced countries. The result implies that developing countries are subject to no less, if not greater competition, than advanced countries. ${ }^{108}$ The study examiners also find that the possible sources of statistic bias in the empirical results do not affect their main conclusions. ${ }^{109}$

Tybout reviewed empirical researches and summarized Indeed, although the issue remains open, the existing empirical literature does not support the notion that LDC manufactures are relatively stagnant and inefficient. Turnover rates in plants and jobs are at least as high as those found in the OECD, and the amount of cross-plant dispersion in measured productivity rates is not generally greater. Also, although small-scale production is relatively common in LDCs, there do not appear to be major potential gains from better exploitation of scale economics. ${ }^{110}$

These studies point out that there is no obvious relationship between

${ }_{105}$ Pradeep S. Mehta, Supra note 85, at 85.

106 Ibid.

107 Referred to by Ajit Singh, Supra note 87, at 4-6.

108 Ibid.

109 Jack Glen \& Ajit Singh, Supra note 76.

i10 Referred to by Ajit Singh, Supra note 87 , at 6 . 
competition law and competition because many developing economies have been able to maintain considerable competition in product markets despite the absence of formal competition laws.

\subsection{Lack of affirmative relationship between competition law and economic growth}

The relationship between competition law and economic growth is an important factor to decide the necessity of competition law. Thus, what is the relationship between competition law and economic development? Would competition law guarantee economic growth? Economic orthodoxy suggests that the greater intensity of competition, the better economic performance. ${ }^{111}$

However, several researchers have demonstrated the opposite viewpoint. For instance, at the microeconomic level, it is recognized that the case for competition necessarily spurring economic efficiency is very weak because of the separation of management and control in large corporations, asymmetric information, transaction costs and agency problems. ${ }^{112}$ Nickell argues that the benefits of competition are more convincing at the broad-brush impressionistic level rather than on the bases of rigorous econometric studies, and proposes that the case for a positive link between competition and increased efforts by economic agents is both theoretically fragile and has little empirical support. ${ }^{113}$

\section{Anti-monopoly law's history in Japan}

To further illustrate the relationship between competition law and economic development, this section will review the historical experience of

\footnotetext{
III Ajit Singh, Supra note 87, at 7 .

112 Ibid.

113 Referred to by Ajit Singh, Supra note 87 , at 7 .
} 
Japan with its Anti-Monopoly Act (AMA), because of Japan's dramatic economic success. Particularly prior to the 1980s, the Japanese enforcement of its AMA was exceedingly slack. The lack of tight enforcement is often cited as one of the characteristics of the Japanese government's behavior during the postwar period. What are the reasons for slack enforcement of AMA in postwar Japan?

A primary reason is that the Japanese government pursued an industrial policy that played a crucial role in Japan's economic miracle during the postwar period. To enhance the competitiveness of Japanese firms in the international market and catch up with more advanced economies, Japanese ministries, most notably the Ministry of International Trade and Industry (MITI), adopted various measures that contradicted the principle of fair competition. As noted by Caves and Uekusa,

...One has been to promote the movement of resources to certain favored industries... another goal has been to promote larger operations in certain industries---larger plants because of an abiding faith in economics of scale, and larger firms in belief that...Japanese firms should be as large as their American competitors in order to compete with them effectively. This goal has led at times to considerable enthusiasm for mergers and restriction of new entry into industries of interest to MITI... ${ }^{114}$

The pursuit of industrial policy not only affected the efficient enforcement of the AMA, but also impacted on the contents of the AMA. For example, during 1953-1994, there were 1379 exemption cartels to promote large operations. ${ }^{115}$ According to some scholars, "the Japanese government takes a more

114 Referred to by Ping LIN, Supra note 78, at 12.

115 Ping LIN, Supra note 78 , at 13. 
pragmatic approach to antitrust enforcement, one that makes allowance for national goals such as industrials catch-up". ${ }^{116}$ Based on Japan's economic miracle after the Second World War, it seems fair for the government to put more weight on industrial policy than on competition policy/law.

However, since the early 1990s, especially since 1995, to get the economy out of recession, the Japanese government initiated a series of comprehensive plans for economic restructuring. A major part of these plans is to promote competition. For instance, deregulation was put into practice in important sectors of the economy, such as telecommunications, energy and transportation. ${ }^{117}$ In June 1990, the Japanese Fair Trade Commission (JFTC) proclaimed a policy to aggressively bring criminal accusations for anti-competitive behavior. ${ }^{118}$ The Japanese government also reduced the number of exemption cartels that were allowed by the AMA and other laws, so that the number of cartels implemented dropped from a peak of 1079 cases at the end of March 1996 to 15 cases under 4 laws at the end of April $2000 .^{119}$

In 2001, a system was introduced for the first time, whereby, those people who suffer from unfair trade practice can file suits in courts seeking injunctive relief against violations of the AMA. ${ }^{120}$ This represents a big improvement in civil remedy for the AMA violations. Another significant development is exercising measures that limit the potential anti-competitive impacts of the

\footnotetext{
116 Referred to by Ping LIN, Supra note 78, at 13.

117 Ping LIN, Supra note 78, at 14.

118 Ibid.

119 Ibid. at 14-15.

120) Ibid.
} 
administrative guidance that was prevalent in the government-business relationships. For instance, in the Deregulation Promotion Plan, the Japanese government requested competent ministries to consult with the JFTC in advance of the issuance of administrative guidance. ${ }^{121}$ In 1994 , the JFTC published "AMA Guidelines on Administrative Guidance" that emphasize that, as for the administrative guidance that may lead to anti-competitive business activities, various ministries should consult with the JFTC before issuing the administrative guidance. ${ }^{122}$

In summary, Japan's competition law/policy has been in place for more than half a century. Prior to the 1990s, competition law/policy played a subordinate role in Japan's regulatory policies. The pursuit of industrial policy mainly through controlling and guiding investment, and permitting cartels denied competition principles. Since the early 1990s, however, both the contents and enforcement of the Japanese AMA have been dramatically developed. The law now has more "teeth" and on the whole is no less comprehensive than competition law in any other country. JFTC is now more powerful, more independent, more visible, and more active. ${ }^{123}$

Focusing on the experience of Japan with its antimonopoly regime, it is important to understand why in the 1990s, there was the shift on the contents and enforcement of the AMA. Why, before the 1990s, was the Japanese AMA enforced slackly? Why, since the 1990s, have the contents of Japanese AMA

\footnotetext{
121 Ibid.

122 Ibid.

123 Ibid.
} 
been strengthened and their enforcement been improved as well? Before the 1990s, besides the crucial element, namely, the pursuit of industrial policy, there were two other factors that combined to work against an empowerment of the JFTC and the AMA. ${ }^{124}$ First, there was a lack of public awareness of antimonopoly. There was little common understanding of the AMA's contents. The general public was not clear what exactly the law permitted or prohibited, offering little support for the stricter AMA enforcement. Second, a total of 31,745 private antitrust suits were brought in the U.S. between 1945 and 1988, while, only 18 such suits were filed in Japan in that same period. In other words, in the U.S., private damage actions were a primary part of antitrust violations, however, largely because of high costs and low probability of success, private antimonopoly lawsuits were extremely rare in Japan. Thus, improving the public's incentive on finding out antimonopoly activities and reporting these violations increases the efficiency of the enforcement of the AMA.

In order to restructure the economy by stimulating competition to increase production ability, since the 1990s, the Japanese government preferred competition policy/law to industrial policy. In administration, the Japanese government requests competent agencies to consult with the JFTC in advance, which can limit policies that go against competition law/policy. Also, the Japanese government has built and developed a healthy competition culture,

${ }^{124}$ Referred to by Ping LIN, Supra note 78, at 18. This is Schaede's study. 
especially by improvement in civil remedy and aggressive criminal accusations.

In summary, Japan's post-war economic miracle was largely achieved by subordinating competition law/policy to industrial policy. The succeeding modifications of the competition regime were responses to economic factors. The Japanese experience was pragmatic, with roots in industrial requirements. At a given time, to gain international competitiveness in certain industrial sectors, it is necessary to subordinate competition law/policy to industrial policy. While, at another time, when the industry requires competition for further economic development, intrafirm rivalries are needed. Although industrial policy and competition policy exist at the same time, depending on specific conditions, it is wise for the government to put one superior to the other one.

In addition, the Japanese experience with its AMA also sheds light on how to build an independent enforcement agency, especially its recommendations on consulting with the JFTC before issuing administrative guidance. ${ }^{125}$ This suggestion is helpful for the government to balance various interests and to determine which policy should be entitled priority in a specific period.

\section{An Egyptian approach-----distinguishing competition law from competition policy}

The adoption of competition law by countries, especially by developing and transitional economies, has experienced an unprecedented growth in the 1990s. In October 2001, there were more than 90 countries with competition

${ }^{125}$ Ping LIN, Supra note 78 , at 18. 
laws. ${ }^{126}$ However, the degree of success in enforcing competition law is relatively low in the majority of developing and transitional countries. What are the reasons for these low enforcements? As discussed in section 3 of this part, the main reason is that there are conflicts between competition law/policy and industrial policy. Most developing countries separate competition law/policy from industrial policy. They regard competition law/policy and industrial policy as two isolated parts. As illustrated by the development of antimonopoly law in Japan, the Japanese government separates competition law/policy from industrial policy as well. According to the realistic social needs, at different times, the Japanese government has different attitudes to competition law/policy and industrial policy. It can put competition policy/law subordinate to industrial policy or industrial policy subordinate to competition law/policy.

Another perspective is that of Egypt. From Egypt's viewpoint, ${ }^{127}$ the crucial reason for the inefficient enforcement of competition law is that developing countries mix competition law and competition policy. Egypt considers that competition law is only a part of competition policy. Industrial policy is also a component of competition policy. Because both competition law and industrial policy are elements of competition policy, the relationship between competition law and industrial policy is complementary.

According to Khemani and Dutz (1995),

Competition policy ... is defined in the broad sense as consisting

\footnotetext{
126 Ahmed Farouk Ghoneim, "Competition Law and Competition Policy: What does Egypt Really Need?", Economic Research Forum, available online: <http://www.erf.org.eg/nletter/Newsletter_Winter02/NewsletterWinterlssue03-P18.pdf > at 1 .

127 Ibid. at 2 .
} 
of two parts-one which is commonly referred to as antitrust or competition law and the other, which compromises micro industrial policies such as tariff and non-tariff policies, foreign direct investment, unnecessary government intervention in the market place and economic regulation designed to prevent anti-competitive business practices by firms. Both parts of the policy impact on economic agents in the market place. ${ }^{128}$

Competition law is just one of a broad set of policy tools required for creating an efficient market economy and as such competition law cannot be considered in an isolated manner. ${ }^{129}$ The law itself can never guarantee that a market will function effectively unless a range of other government policies conform to basic market principles. Sets of policies, such as trade policy, including tariffs, quotas, and subsidies, antidumping actions, domestic content regulations, and export restraints, industrial policy, regional development policy, intellectual property policy, privatization and regulatory reforms, science and technology policy, investment and tax policies, licenses for trades and professions all need to be conducted in a manner compatible with the market mechanism for an economy to function as efficiently as possible. ${ }^{130}$ To establish and develop an efficient market economy, besides competition law, all other policies need to be practiced in a complementary manner, and it is important that a mechanism exists for incorporating the "competition dimension" within government decisions on such policies. ${ }^{131}$ In a word, the failure of competition policy can vitally result in the failure of competition law; however, the inefficient enforcement of competition law does not mean the

\footnotetext{
${ }^{128}$ Referred to by Ahmed Farouk Ghoneim, Supra note 126, at 2.

129 Ahmed Farouk Ghoneim, Supra note 126, at 6.

130 Ibid. at 12

131 Ibid.
} 
inefficiency or absolute collapse of competition policy.

There are opinions that underline the importance of the competition nature of the market economy rather than solely adopting competition law. For example, the World Bank's World Development Report 2001 asserted, "in resource-constrained countries, governments may benefit from focusing on removing barriers to entry and exit in markets and opening the economy to international competition before turning their attention to building competition laws and agencies". ${ }^{132}$ The OECD states, "competition policy instruments are blunt, not refined, surgical instruments and have to be handled with care. For countries without experience in this field, a rules-based approach to competition would be appropriate and there should be the fullest interplay for market forces and mobility of resources, deregulation and lowering of barriers to entry as instruments for promoting competition rather than law itself". ${ }^{133}$ In summary, to implement competition law efficiently, it is preferable for developing countries to establish a competitive market first by developing other major pillars of competition policy, such as sticking to trade liberalization policy and eliminating barriers to entry and exit.

132 Ibid. at 15

133 Ibid. 


\section{Part IV}

\section{A possible International Competition Law}

Faced with the Asian crisis of 1997-2000, several international organizations, such as the OECD and the UNCTAD, are involved in the reforms of competition laws and policies in those crisis economies. ${ }^{134}$ Moreover, in order to remove internal and external barriers to trade, developed economies are seeking to establish an international competition agreement in the WTO. This suggestion, however, is vetoed by developing countries. What are the reasons for the dissimilar opinion between developed and developing countries on the introduction of a multilateral competition law? What are the suggested contents of a possible international competition law? This part will seek answers on the above two questions.

Section 1 examines reasons put forward by developed economies for the necessity of establishing an international competition law. Sections 2 and 3 highlight the objectives, principles and contents of a possible international competition law, namely, the EU's proposal and the WGITCNGTCP's recommendations. Section 4 focuses on developing countries' perspective on the possible multilateral competition law.

1. Developed countries' perspective: the necessity of competition policy in the World Trade Organization

1.1 Limitations of the current competition-related provisions in the GATT and GATS

With the increasing of trade liberalization, cartels are "looming as a major

\footnotetext{
134 Jack Glen \& Ajii Singh, Supra note 76.
} 
enforcement concern...it's almost as if private arrangements are replacing governmentally imposed market barriers". ${ }^{135}$ International cartels are engaged in price fixing, division of market at the international level, establishing pricing ceilings or floors and providing mechanisms to prevent new entrants. Current WTO agreements embrace several competition-related provisions both in the GATT and the General Agreement on Trade in Services (GATS). However, these provisions only focus on government measures, not members' regulation of private enterprises' anti-competitive behavior such as cartels. This means that private anti-competitive practices are not restricted within the realm of the existing WTO rules. For example, ${ }^{136}$ Article XI of GATT prohibits members from imposing quantitative restrictions as well as "measures other than duties" on importing and exporting. This only indicates that members cannot pass domestic rules and regulations that can lead to restrictions of exports or imports, but no consideration is given to members' regulation of private firms' anti-competitive activities. Article XI b) of GATT also only applies to government measures that may restrict the importing and exporting of goods across a border but not the production of those goods behind the border. GATS does not address government regulation of private anti-competitive practice, either. ${ }^{137}$

Because of the limitations of the current competition-related provisions in

\footnotetext{
135 Bahaa Ali El Dean \& Mahmoud Mohieldin, "On the Formulation and Enforcement of Competition Law in Emerging Economies: The Case of Egypt", available online: <http://www.eldis.org/static/DOC11407.htm> at 26. 136 Deunden Nikomborirak, "VI: Competition Policy in the World Trade Organization: How to make it a developing country's agenda", United Nations Economic and Social Commission for Asia and the Pacific, available online: <http://www.unescap.org/tid/publication/chap6_2278.pdf>.

${ }_{137}$ Ibid.
} 
the GATT and GATS, it is argued that it is necessary to set up a competition policy in the WTO. Unlike trade policy, competition policy emphasizes government regulation of private activities rather than state practices. ${ }^{138}$ In addition, at the national level, a national competition regime assures competition in the domestic market, while at the global level, a multilateral competition rule can be a tool used to deal with cross-border restrictive business practices, such as cartels. ${ }^{139}$ Thus, an international competition policy can fill in the gaps not covered by the GATT and GATS and address competition concerns of both developed and developing economies.

\subsection{Developing countries will gain from a multilateral competition agreement}

The Working Group on the Interaction between Trade and Competition Policy (WGITCMGTCP) recognizes that hard-core cartels (defined in section 4.2 of this part) undermine the potential benefits of trade liberalization and inflict heavy costs, particularly on developing countries that lack bargaining power, resources and capacities to deal with such cartels. For instance, generally, in cartel-affected imports, US\$20 billion to US\$25 billion has become the annual external cost to developing countries. These amounts are almost double the amount of welfare gains that would result from a worldwide cut in agricultural subsidies by 50 percent, which is estimated to be US\$13.4 billion. ${ }^{140}$ In fact, all of the above figures could be much higher. Cartels of a

\footnotetext{
138 Competition Policy in the WTO is also a kind of regulation of government practices because private anti-competitive activities are restricted by states. In practicing a multilateral competition law, members of governments take roles as middlemen.

${ }_{39}$ Deunden Nikomborirak, Supra note 136.

140 Ibid.
} 
global scale may operate secretly in many countries and thus remain elusive to national competition laws. ${ }^{141}$ Therefore, developing economies will gain from a multilateral competition agreement that can efficiently ban hard-core cartels.

\subsection{Problems arising from enforcement}

There are three aspects of weakness from unilateral enforcement of competition law. First, unless cartels affect the domestic market, countries, such as the EU, the US, Germany, Korea and Japan, seldom enforce competition laws that are against "pure" export cartels, cartelized products of which are sold to foreign consumers. ${ }^{142}$

Second, faced with the transnational and anticompetitive impacts from the increasing number of private business activities, neither the United States nor the EU limits its antitrust enforcement to national firms within the domestic territory. When an external activity causes a negative effect on their markets, consumers and exports, both of them will apply their competition laws extraterritorially. ${ }^{143}$ However, the extraterritorial application has pushed a number of countries, such as Canada, the U.K., Germany, the Netherlands, France, and Switzerland, to adopt so-called blocking statutes, which are designed to counteract the influence of the extraterritorial jurisdiction by prohibiting cooperation with foreign authorities. ${ }^{144}$

Thirdly, even though a competition agency can claim extraterritorial

\footnotetext{
141 Ibid.

142 Ibid.

143 Youri Devuyst, "Toward a Multilateral Competition Policy Regime" (2000) 6 Global Governance, at 5-6.

144 Ibid. al 6.
} 
jurisdiction, the competition authority may find that it is hard to collect the information for the investigation because it is often located outside of the authority's jurisdiction. ${ }^{145}$ It is also necessary to avoid conflicts of laws and remedies in international cases, and to keep away from the needless duplication of work and costs. ${ }^{146}$ An international competition law will bring more advantages to open competition than those of individual domestic competition law through ensuring the effective enforcement of competition laws and avoiding drawbacks of extraterritorial jurisdiction.

\section{The EU's proposal for an international competition framework}

Since 1996, the EU has been the most insistent proponent of a multilateral competition framework. Currently, the EU recommends a proposal for adding competition regulations into the WTO. The proposal includes:

1. A prohibition (or ban) on hard core cartels to be enacted into domestic law of the WTO (domestic law of memibers of the WTO);

2. The right of domestic exclusions and exemptions, but listed and transparent;

3. The application of binding core principles (national treatment but modified) as to national competition laws;

4. WTO Dispute Settlement on core principles for all national law provisions. Possible peer review as to non-binding elements;

5. A voluntary (non-binding) co-operation mechanism to assist member's investigation and enforcement as to foreign practices;

6. Special and differential treatment as to time of compliance, technical assistance etc;

7. Establishment of a WTO competition policy committee. ${ }^{147}$

\footnotetext{
145 Ibid. at 6-7.

146 Ibid.

147 James H. Mathis, "Competition and Regulation Policies in the WTO: Implications of a Multilateral Competition Policy Framework", Jamaica Fair Trading Commission, available online:

$<\mathrm{http} / /$ www.jftc.com/events/10th\%20Anniversary/SPL/James\%20Mathis\%20Lecture\%20powerpoint\%20show.pp 1>at 6-7.
} 
In this proposal, there are three important principles: transparency, non-discrimination and procedural fairness. The transparency principle requires coverage of all aspects of the competition regime, namely, from legislation, rules and institutional structures to decision-making processes, including decisions on sectoral exclusions and exemptions. This would represent an extension of the transparency requirement in the current WTO (GATT, Article $X$ ) that is restricted only to the publication of trade regulations and does not include decision-making. ${ }^{148}$

Non-discrimination encompasses most-favored-nation treatment (MFN) and national treatment (NT). The MFN principle requires that products made in one member country be treated no less favorably than "like" goods that originate in any other country. ${ }^{149}$ The NT requires members not to grant a more favorable treatment to their nationals, goods or services. It highlights that members should permit access to the mechanisms and procedures of their national competition laws on a non-discriminatory basis to natural or legal persons resident in the territory of any party. ${ }^{150}$

Procedural fairness is an important component of the non-discrimination principle as well. It can guarantee rights of access to the system of appeal, including the right to have detailed grounds of decision-making, and the right of

\footnotetext{
148 "TWN Cancun Briefings 5-Trade and Competition Policy in the WTO", TWN Africa, available online: $<$ http://twnafrica.org/news_detail.asp?twnID=495>.

149 Bernard M. Hoekman, Aaditya Mattoo \& Philip English, "Development, Trade, and the WTO: A Handbook", available online:

$<$ http:/www.amazon.com/gp/product082134997X/104-1518953-6263138? v=glance\&n=283155\&v=glance > at 42.

150 TWN Africa, Supra note 148.
} 
parties to be heard. ${ }^{151}$

\section{The WGITC/WGTCP's recommendations}

After the Ministerial Meeting at Cancun, in September 2003, the WGITCMGTCP has been continued asking for the clarification of specific issues that might form a multilateral competition framework for the possible negotiations in the coming Round. These issues, spelled out in paragraphs 23 to 25 of the Doha Ministerial Declaration, are as follows. ${ }^{152}$

\section{Transparency}

As for transparency, members should ensure that the publication of laws, regulations and guidelines of general application as well as exclusions and exemptions are available to the public either in an official gazette or journal or in electronic form on a web site. The transparency obligation may also involve mandatory notification of these documents to the WTO. ${ }^{153}$

\section{Procedural fairness}

Procedural fairness underlines that members should guarantee that parties facing adverse decisions and sanctions are given sufficiently basic rights to defend their cases. These include the rights to: a) be notified that a formal investigation is pending against them; b) submit evidence and documents, and present their views to the authorities concerned, either in writing or by participating in public hearings; c) appeal; and d) protect

\footnotetext{
151 Ibid.

152 Deunden Nikomborirak, Supra note 136. Or see "Doha WTO Ministerial 2001: Ministerial Declaration", the World Trade Organization, available online: $<$ http://www.wto.org/english/thewto_e/minist_e/min01_e/mindecl_e.htm\#trips $>$.

15.3 Deunden Nikomborirak, Supra note 136.
} 
confidential information that is submitted to the authorities. ${ }^{154}$

\section{National treatment}

The definition of national treatment is a little different from those in the GATT and GATS. Specifically, it refers to firms rather than products, which is the case in GATT. That means that the national treatment principle, a part of non-discrimination principle, pays attention to foreign investment rather than foreign trade. ${ }^{155}$

\section{Additional principles}

\section{Special and differential treatment}

Several developing members believe that since the Doha Ministerial Declaration explicitly states, "full account shall be taken of the needs of developing and least-developed country participants" ${ }^{156}$, special and differential treatment should constitute one of the core principles of an international competition regime. The WGITCMGTCP proposes two kinds of flexibility. First, on the bases of transparent procedures and periodical review, developing economies can exempt or exclude certain sectors or businesses from national competition laws or regimes in order to achieve other national objectives, such as social, economic and industrial development. ${ }^{157}$ The second is about compliance transition periods that allow an extended period for phasing in the introduction and implementation of competition legislation in developing countries without a national competition law, or those with such

154 Ibid.

155 Ibid.

156 Ibid. 
laws but which face implementation problems. ${ }^{158}$ in a word, special and differential treatment refers to special rights and more favorable treatments for developing countries in meeting their WTO obligations.

\section{Comprehensiveness}

Another core principle, comprehensiveness, is a response to concerns that excessive proliferation of exemptions and exclusions may weaken the value of a multilateral competition agreement. ${ }^{159}$ Although comprehensiveness is not among the core principles of the WTO, it is one of the four principles in the APEC Principles to Enhance Competition and Regulatory Reform. Comprehensiveness could ensure that there is sufficiently broad application of competition principles to economic activities. It advocates that exemptions and exclusions should be designed in a way that minimize distortion of the competition process, and are subjected to periodic re-examination within the context of the overall framework agreement. ${ }^{160}$

4. Developing countries' perspective: continuing clarification of the objectives, main principles and concepts of an international competition law is better than the start of negotiations

At several recent regional meetings (the Conference of African Ministers of Trade in Mauritius, the Dhaka Declaration Conference of Least Developed Countries and the Meeting of ACP Ministers in Brussels), Trade Ministers of developing countries have explicitly stated their unwillingness to start negotiations on a multilateral competition framework. ${ }^{161}$ More recently, in a

\footnotetext{
158 Ibid

159 Ibid.

160 Ibid.

161 TWN Africa, Supra note 148.
} 
communication to the Ministerial Conference, the group of Least-developed

countries (LDCs) together with 15 other countries (Botswana, China, Cuba,

Egypt, India, Indonesia, Kenya, Malaysia, Nigeria, Philippines, Tanzania,

Uganda, Venezuela, Zambia and Zimbabwe) stated that they prefer to

continue clarifying the contents of an international competition law rather than

start new negotiations. ${ }^{162}$ What are the reasons for this standpoint? The

following subsections will offer answers to this question.

\subsection{Developing countries' comprehension of an international competition law}

Developing economies, from the development perspective, consider that a competition and development framework requires local industrial and service

firms to build up capacities to become more and more competitive in the international market. Because this cannot be done in a short time, but requires

a long time frame, the governments also need to play the role of nurturing, subsidizing $^{163}$ and encouraging local firms, and protect their domestic firms

\footnotetext{
162 Ibid.

163 It could result in much more anti-subsidy cases for developing countries, and even the misuse of anti-subsidy actions in real practice in the world, like the abuse of antidumping investigations. When developed economies initiate anti-subsidy investigations against developing countries, developing economies can initiate anti-subsidy actions against developed countries as well. Developed countries provide direct subsidies to a variety of products, as pointed out by developing countries in the WTO Ministerial Conference held at Cancún, Mexico. For example, the U.S. government annually supplies subsidies to Cotton producers amounting to over US $\$ 3$ billon. See "Chairman's Speech", The Cotton Textiles Export Promotion Council (TEXPROCIL), on September 21 available online: <http://texprocil.com/speech1.htm>. Also, to cope with the World Bank and IMF anti-subsidy policies that are designed to prevent imports of goods for which prices are kept artificially low by public subsidies in the third country of origin, and to challenge developed economies' anti-subsidy investigations, based on the Declaration by the Group of 77 and China on the Fourth WTO Ministerial Conference at Doha, Qatar, developing countries argue for an application of moratorium and even elimination on anti-subsidy measures resorted to by developed states (sections 6\&15), and highlight putting the development dimension into the development of multilateral trading system (MTS), flexible criteria and obligations commensurate with their stages of development (section24), and precisely and effectively special and different treatment, such as reciprocal obligations, in favor of their interests, such as greater market access to the developed countries' markets for the exports of developing economies (sections 6,7\&24). See "Declaration by the Group of 77 and China on the Fourth WTO Ministerial Conference at Doha, Qatar", The Group of 77 at the United Nations, available online: $<$ http://www.g77.org/Docs/Doha.htm>. Or see Medicine Masiiwa, "Statement on the WTO DOHA Ministerial Declaration". Trade and Development Studies Center (TRADES), available online: <http://www.sarpn.org.za/CountryPovertyPapers/Zimbabwe/may2002/trade.php>. The thesis will not explore subsidies and countervailing measures since they are beyond the scope of this thesis.
} 
from free international trade or international competition for sufficient time to promote their national competitiveness. ${ }^{164}$ In April 2003, in Arusha, Tanzania, trade officials from fifteen African countries declared "our understanding of competition policy, from the development perspective, is that there is a need for government to assist and promote local firms so that they can be viable and develop despite their present relative weakness, so that they can successfully compete with foreign firms and their products". ${ }^{165}$

From developing countries' perspective, the first task is development, not the pursuit of competition. Thus, competition law/policy, as an element of a set of policies to achieve the development goal, should take a complementary role. Any possible international competition law needs to be regarded as a tool to gain the first mission as well. Many developing countries argue that principles of international competition law should not be too authoritarian and intrusive in order to allow each member the flexibility to design its individual administrative procedures that not only match with the principles, but are also consistent with local legal tradition, industrial policy, institutional design and socio-political environment. ${ }^{166}$ Obligations under the possible international competition law should focus on "achieving the end results" rather than on "prescribing the means". 167

However, it is hard to establish an international competition law since

\footnotetext{
164 TWN Africa, Supra note 148.

165 Aziz Choudry, "Another Corporate Steal? The Proposed WTO Competition Policy", 2004, available online: <http://www.incsoc.net/asean-rep.doc>.

166 Ibid.

167 Deunden Nikomborirak, Supra note 136.
} 
countries at different stages of development have different development interests, and regard competition issues differently. The Indian industry minister, Mr. Jaitley believes that the WTO members are too diverse to set up a framework that would be suitable for all. A competition agreement can only occur between countries at similar stages of development. ${ }^{168}$

\subsection{Developing countries' comments on the EU's proposal and the WGITC/WGTCP's recommendations}

\section{Transparency}

The requirement for publishing "judicial decisions and administrative rulings of general application"169 would be unduly troublesome, especially for developing countries, and potentially unworkable in the context of competition policy because different authorities have different administrative rules regarding what kind of information can be disclosed and what type must be kept secret.

\section{Non-discrimination}

The non-discrimination principle, especially the national treatment principle, is a market access approach since it implies that foreign enterprises should be entitled to equal opportunities to compete with local firms in the local market, and that government should not give preference or assistance to local firms. Such so-called "equality" would only accentuate the inequality in market outcomes since local firms are generally smaller than large foreign firms and

\footnotetext{
${ }^{168}$ Gumisai Mutume, "New WTO proposals stir controversy: Singapore issues could undermine local enterprises in Africa", Africa Recovery, available online:

<http://www.un.org/ecosocdev/geninfo/afrec/vol17no4/174wto.htm>.

169 Deunden Nikomborirak, Supra note 136.
} 
transnational corporations (TNCs), and thus would be driven out of the market. ${ }^{170}$

More important, it is necessary for developing countries' governments to provide advantages for local firms in order to increase their economies of scale, and in order for them to survive in the international competition. Many developed countries also have practiced sets of preference strategies to develop their firms' international competitiveness to achieve their eventual ambition, namely, economic development. For example, between 1950-73, during its rapid industrial and economic development phase, in order to increase domestic firms' abilities to compete with developed nations' enterprises, the Japanese government interfered to support local enterprises, directing investment, restricting market competition, encouraging various cartel arrangements and mergers among domestic firms, and applying positive discrimination between the needs of domestic firms for the development of a national economy and the market access needs of foreign companies in the local market. ${ }^{171}$ South Korea, in the process of industrialization, also practiced similar paths, such as strong intervention and slack competition policy. ${ }^{172}$ Also, these means practiced by Japan and South Korea have been proved and emphasized. Bill Rosenberg, a New Zealand trade and investment analyst, comments, "the large industrial economies had effective protection from competition long after their industry took root, through explicit or informal rules,

\footnotetext{
170 Ibid.

171 Aziz Choudry, Supra note 165.

172 Ibid.
} 
or from being first into a market. That greatly helped their development". ${ }^{173}$

Only an equal starting point can lead to equal competition. Increasing

local firms' competition ability in the international market is a key for developing

countries to get an equal starting point. Therefore, it is necessary and reasonable for developing countries to put preference approaches into practice to obtain the vital precondition of the equal international competition level. The non-discrimination principle is inappropriate for developing countries. ${ }^{174}$ As Bhagirath Lal Das, the Indian former Ambassador and Permanent Representative to the GATT, states, "a developing country may like to give special treatment to its domestic trading firms in the matter of taxation, use of domestic distribution channels, etc, while denying these advantages to the foreign trading firms". ${ }^{175}$ Also, a perspective from Hong Kong states, “... many Members have horizontal (e.g. statutory monopolies, small and medium enterprises (SMEs), Research and Development agreements, efficiency enhancing measures and other efficiency enhancing arrangements) or sectoral (e.g. agriculture and

\footnotetext{
173 Ibid.

174 As stated in section 3 of this part, the national treatment principle, a part of non-discrimination principle, expands the definition of national treatment in GATT and GATS. Specifically, it refers to firms rather than products, which is the case in GATT. That means that the national treatment principle pays attention to foreign investment rather than foreign trade. It would allow unlimited operation of market-seeking foreign investors without any cognizance of the development dimension and national priorities. As pointed out in footnote 163 , developing countries underline the imbalances arising from the Uruguay Round Agreement and inequitable distribution of benefits and losses and other negative effects arising from the WTO agreement (section $4 \& 5$ of the Declaration by the Group of 77 and China on the Fourth WTO Ministerial Conference at Doha, Qatar). Especially, as for the market access, developing countries ask for market access to the developed countries' markets for their exports, while, there is no development in the WTO agreement in favor of their interests. In developed economies, there are still tariff peaks, tariff escalations and other non-tariff barriers such as arbitrary and complex rules of origin, technical barriers to trade, and sanitary measures used for protectionist purposes (section6). On the contrary, developed economies have had greater market access to developing counties' markets by the national treatment and the non-discrimination principle in the GATT and GATS. Expanding the national treatment principle from foreign trade to foreign investment will enlarge developed countries' market access rights to developing economies' markets, and increase the imbalances arising from the WTO agreement and inequitable distribution of benefits and losses due to developing countries' low investment abilities to developed economies' markets. From this aspect, the non-discrimination principle of the possible international competition law, including the national treatment principle, will result in more negative impacts on developing countries. See Digvijay Singh, "Reflections on Doha Ministerial of the WTO: Issues and Options", Federation of Indian Chambers of Commerce and Industry (FlCCI), available online: <http://www.ficci.com/ficci/media-room/speeches-presentations/2001/aug/aug27-wto-digvijaysingh.htm>.

175 Aziz Choudry, Supra note 165.
} 
petroleum) exemptions or exceptions in their competition laws and/or policies. These exemptions and exceptions may not be fully consistent with the principle of non-discrimination, particularly in respect of national treatment. Developing Members, in particular, may have provided for exemptions or exceptions in their competition policy in view of other overriding economic, industrial or developmental policies. Therefore, certain elements of non-discrimination, if included as obligations under a possible MFC, may cause difficulties for some Members". ${ }^{176}$

\section{Procedural fairness}

A concern is that developing countries with dissimilar legal systems to developed countries, or with insufficient resources will run the risk of not meeting the required standard of procedural fairness. Also, notions of fundamental fairness are different among legal systems, political and legal cultures, and there is as yet no broad consensus on the meaning of procedural fairness in the context of competition law enforcement. ${ }^{177}$

\section{Hard-core cartels}

A fundamental problem in the EU's proposal is the definition of hard-core cartels. Currently, two definitions of hard-core cartels are to be found in non-binding agreements concerning cartels. One is the definition, provided by the OECD Council's Recommendation Concerning Effective Action against Hard-Core Cartels, which includes price fixing, quantity fixing, market allocation and bid rigging. ${ }^{178}$ The other definition can be found in the UNCTAD non-binding recommendations of 1980 for the control of restrictive business practices, in particular cartels, known as the "Multilaterally Agreed Equitable

\footnotetext{
176 James H. Mathis, Supra note 147, at 8-9.

177 Deunden Nikomborirak, Supra note 136.

178 Ibid.
} 
Principles and Rules for the Control of Restrictive Business Practices", or the "Set" in short. According to the Set, besides the four types of collusive practices specified in the OECD recommendation, hard-core cartels also include a concerted refusal to supply potential importers, collective denial of access to an arrangement or association, and collective action to enforce a cartel arrangement, such as a refusal to deal. ${ }^{179}$ However, until now, there is no generally accepted definition of hard-core cartels among countries.

The assumption that all hard-core cartels have harmful influence on all countries in all markets at all stages of their development is questionable. Based on some Asian countries' experience, cartelization, as a component of their industrial policies, challenges this assumption. ${ }^{180}$ Additionally, based on overriding economic or public interest grounds, nearly all developed economies have had exemptions (and continue to maintain some of them); and allow cooperation among small and medium sized enterprises (SMEs) to countervail the market power of a dominant firm. Although there is no definite scope on the exemptions or exclusions, exemptions or exclusions' existences are allowed. ${ }^{181}$

Developing countries are more complex. For example, developing countries prefer reserving the right to exempt cartels that consist of SMEs; treat domestic and international cartels differently due to the overwhelming difference in the size of domestic and global markets; and consider that 179 Ibid.
${ }^{180}$ TWN Africa, Supra note 148.
181 Ibid. 
exemptions and exclusions may change based on given economic and socio-political situations. ${ }^{182}$ In short, as for the questions, what kinds of collusive practices would be considered as "hard-core" cartels; whether the definition should be the same for cross-border versus domestic cartels; and whether the definition of hard-core cartels should include or exclude government, government-mandated and private export cartels, ${ }^{183}$ there is no consensus among countries. The multilateral prohibition on hard-core cartels will restrict flexibilities of policies, especially for developing countries.

In addition, some members do not believe that having an international competition law that prohibits hard-core cartels will be sufficient to solve cross-border cartel problems. For instance, even if a domestic competition authority finds that foreign firms are guilty of raising prices of imported goods or services, those firms do not need to obey remedial measures or sanctions imposed upon them, unless those firms have assets in the importing country or the affected parties are considered important customers. ${ }^{184}$ There is nothing that a national competition authority or court can effectively do when there are no reasonable substitutes for the imported products. ${ }^{185}$

\section{Special and differential treatment}

As for the recommendations on special and different treatment for developing countries, proposed by the WGITCMGTCP, there are questions

\footnotetext{
182 Deunden Nikomborirak, Supra note 136.

183 lbid.

184 Ibid.

185 Ibid.
} 
raised on both types of flexibility. With regard to exemptions and exceptions, certain members state that the proliferation of exemptions and exceptions might undermine the value of a competition regime. Thus, it is useful to put "comprehensiveness" into the core principles as well. Comprehensiveness can ensure that a competition regime maintains an acceptable scope of application. Exemptions and exceptions, provided for international cartels, should not be allowed when cross-border restrictive business practices take place. ${ }^{186}$ Regarding a transition period, certain developing countries propose that it is reasonable to link it with each member's level of development rather than emphasizing a fixed period that could be inappropriate and arbitrary. ${ }^{187}$ In an international competition framework, it is logical to exclude members from obligation until their development level reaches the predetermined threshold.

However, scholars do not believe that the proposed flexibility and progressiveness (a transition period) will meet the needs of developing countries. As for the flexibility to exempt particular sectors or industries from the competition law, developing countries consider that based on the reciprocal principle of the WTO, exclusions and exemptions do not represent special and differential treatment for them since developed countries are also allowed to make exemptions. ${ }^{188}$ It is also difficult for developing states to master the scope of practicing exceptions and exemptions since developed economies will argue its acceptableness by the comprehensiveness principle.

\footnotetext{
186 Ibid.

187 Ibid.

188 Ibid.
} 
It is hard for progressiveness in the form of a transition period to benefit developing countries if the substantive elements of the pending obligation are not in the interest of such countries. For example, the TRIPs Agreement required all members to comply with the substantive provisions by January $1^{\text {st }}$, 1996. Developing and transitional countries were allowed a transition period up until January $1^{\text {st }}, 2000$, and least developed countries have until January $1^{\text {st }}$, 2006. The delayed compliance does not make the TRIPs any more agreeable to these countries as they simply defer the heavy cost burden to a later date. ${ }^{189}$ Similarly, if the obligation to pass a national competition law and to adopt the proposed core principles will not offer advantage to developing economies to begin with, then transition periods would still be of no advantage to developing countries. $^{190}$

Therefore, there is a suggestion that meaningful, special and differential treatment for developing countries should entail non-reciprocal or unilateral commitments on the part of developed economies. For instance, to effectively cope with cartels, developed nations should practice a unilateral commitment, which can include a) providing cooperation in assisting developing countries in investigations and prosecutions of cartels; b) removing export/international cartel exemptions from their national competition laws; c) obeying core principles in enforcing the law; and d) demonstrating "best efforts" in dealing with cartels that are found to harm other parties by employing administrative 189 Ibid.
190 Ibid. 
measures to sanction export and international cartels. ${ }^{191}$

\section{Conclusion}

The EU's and WGITC/WGTCP's proposals are not appropriate for developing countries. Both of them would significantly affect the flexibility of adopting a fitting model for developing countries' own competition laws/policies that are consistent with their levels of development and developing interests. The two proposals will prohibit governments from measures that support or encourage local enterprises, maximize the rights of foreign enterprises to have market access to developing countries through their products and investment, reduce host governments' rights on regulating foreign investors, and limit developing countries' strategies on shielding their weak firms from severe foreign competition. Besides the grave conflicts on the core principles of the possible multilateral competition law, there is also no common acceptance on the definition of competition law (as stated in section 1 of Part III) and hard-core cartels. Therefore, as claimed by developing countries, continuing clarification on these issues is better than the start of negotiations on setting up a multilateral competition law.

191 Ibid. 


\section{Part V}

\section{The application of the Constitutive theory}

The Constitutive theory ties all of the Parts together by focusing on what defines or constitutes law. The necessity, objective and content of a law rely on its social conditions and requirements. Section 1 applies the theory to the differences in opinion on antidumping law, competition law and a possible multilateral competition law between developed and developing countries. Section 2 considers how the theory informs China's attitude to antidumping law, competition law and a possible international competition law.

\section{Developed v. Developing countries' views}

The Constitutive theory postulates that law itself is defined by a society, and brings constitutive effects on the society. It cannot be separate from the interests, goals, and understandings that comprise a society. A law's rationality and efficiency depends on whether its objectives and contents match with the social needs. Countries can hold different understanding or opinion on a law's purposes and contents due to their different social requirements.

As for antidumping law, based on some limited social needs, namely, restricting developed economies' abuse of it and expanding exports and shares in the international market, developing countries could support replacing antidumping law with competition law. However, based on other larger social requirements, such as caring for infant industries and gaining certain international competitiveness, developing countries, especially 
economies that refuse to open up effectively to the world, would favor the existence and practice of antidumping law in order to protect their domestic producers' interests. Developing nations would put antidumping law into practice not only in cases of unfair competition, namely, predatory pricing, but also in types of geographical price discrimination, which could be business activities that can play a role in increasing competition.

Similarly, most developed countries would have the same opinion as that of developing economies largely because of having the attitude of protecting domestic producers' interests. ${ }^{192}$ For example, the Canadian government supports free trade and favors replacing antidumping law with competition law. Its priority is reduction and even elimination of antidumping investigations in Canada and U.S. trade, however, the United States does not agree with the Canadian proposal. ${ }^{193}$

Faced with the abuse of antidumping law among developed and developing countries, to ensure competitive international trade, it seems necessary to practice competition law. However, according to the Constitutive theory, there is no "one fits all"194 approach on competition law's design and application either. Every economy should formulate its own competition law based on its individual conditions and needs, such as available legal capabilities of enforcement, cultural considerations, economic development

\footnotetext{
192 The governments of the EU within the EU, and the Australian and New Zealand governments within their closer economic relations replace antidumping laws with competition laws in their internal trade.

193 Competition Bureau, Supra note 2.

194 Aziz Choudry, Supra note 165.
} 
stage, and harmonization with industrial policy, development policy and other policies designed to improve economic and social welfare of broader society.

Section 2 of Part III has set out that the potential impacts of the international merger movements and privatization, deregulation and liberalization that have occurred in domestic markets have pushed developing economies to enact their own competition laws. However, developing countries clearly understand that their eventual aim is to sustain long-term economic development. Competition law is just a means to gain the goal of economic development, and not an end itself. Its application should not go against the goal and reduce national competitiveness at the international level, which is a way to achieve the final goal. In other words, the emphasized point of their competition laws should focus on attaining a precondition for competition, namely, having the ability to compete at the international level. Therefore, it is necessary for developing countries to emphasize their competition laws on the basis of dynamic efficiency rather than static efficiency. It is necessary for developing economies to comprehend the coherence between industrial policy and competition policy. Instead of maximum competition, a concept of "optimal degree of competition" ${ }^{\text {195 }}$ that emphasizes a combination between competition and cooperation among firms should be practiced. To maintain private sectors' interest in investment, a steady profit growth is an important precondition. To preserve the prerequisite and to make reasonable investment decisions,

\footnotetext{
195 Ajit Singh \& Rahul Dhumale, "Competition Policy, Development and Developing Countries", South Center--An Intergovernmental Organization of Developing Countries, available online: <http://www.southcentre.org/publications/competition/toc.htm>.
} 
cooperation between government and business is necessary as well.

As for developed economies, competition law is a tool for them to increase competition in order to develop their economy as well. However, the emphasized purpose of developed countries' competition laws is different from that of developing countries' competition laws. The stressed point is that developed countries have gained the competitiveness in the international sphere; thus, they pay attention to promoting competition. They consider that intense and even maximum competition will stimulate innovation for further economic development, such as Japan's practice since the early 1990 s.

To remove internal and external barriers on international trade, several advanced economies suggest establishing a multilateral competition law. As for the attitude to a possible international competition law between developed and developing states, the Constitutive theory supports answers on why developed nations advocate the necessity of adding competition law into the WTO, while developing economies go against the EU's and WGITCMGTCP's recommendations on a possible international competition law. The diverse view held by developing and developed countries results from their dissimilar social phenomena and requisites.

As for developing countries, the attitude to the proposed international competition law is similar with their outlook on their domestic competition laws, namely, both of them are tools to achieve their eventual development goal. The objective, main principles and contents should be consistent with the 
achievement of the end. The proposals from the EU and the WGITCMGTCP are vetoed because they would lead to contradictory consequences on the requirements of societies.

Specifically, developing countries consider that an international competition framework requires the competitiveness of local industrial and service firms in the international market. When there is lack of competitiveness, it is necessary for the governments to nurture, subsidize and encourage domestic firms, and to protect local firms from free international trade. As for developing economies, the proposed principles, especially the national treatment principle, are not consistent with the above necessities, the development perspective, the ultimate goal and fair competition in the international market.

In short, developing countries are not interested in whether there is market access for their domestic enterprises, or whether their national firms operating overseas are protected by a competition regime in a host economy. On the contrary, developing countries are more concerned about stimulating local enterprises' promotion in competitiveness by a set of government aids, curbing mega-mergers and acquisitions to protect local firms' competitive positions in the international competition sphere, and restricting business practices of foreign multinationals, such as price-fixing and bid rigging that lead to higher prices of imported products or services. ${ }^{196}$

196 Ibid. 
Developing economies' interests are contrary to those of developed countries. Developed countries are interested in market access since most of them have investment interests in many developing countries that do not have competition laws or lack efficient protection of foreign enterprises from anti-competitive activities practiced by local industries. A possible international competition law would not only ask for all members to establish national competition regimes, but also increase foreign investors' competition rights in domestic markets by several core principles, particularly, non-discrimination between domestic and foreign companies.

Different social requirements between developing and developed countries reflect two diverse aims of a possible multilateral competition law. Developing countries lay emphasis on restricting private cross-border business practices that affect the prices and availabilities of goods to members, and competitiveness in the international realm. Developed economies underline national treatment and full competition in host markets. Different purposes will result in dissimilar objectives and contents of a possible international competition law. The interests, gained from a possible international competition law between developing and developed countries, largely depend on which aim is held by the WTO. ${ }^{197}$

The Constitutive theory highlights the corresponding nature between the law and the needs of society. Its application will make law become realistic and

197 Ibid. 
implementable, not futile and even counterproductive. If China wants to practice beneficial antidumping law, competition law and a possible international competition law, it is necessary to find out what the social necessities of China truly are, which are valuable to outline the objectives, contents and applications of these laws. The following sections will examine China's attitude to the laws by examining Chinese social phenomena and requisites.

2. China's attitude to antidumping law, competition law and a possible international competition law

\subsection{China's attitude to antidumping law}

As stated in the introduction, since 1995, China has become the favorite target of other countries in the antidumping area since other economies want to protect their domestic industries against imports of cheaper Chinese products. Based on Chinese official data, in 2003, there were 52 cases in this area. The amount in US dollars for these cases was up to 22 million. In the first three months of 2004 , there were 11 relevant cases, an increase of $83.8 \%$. The amount of US dollars was 3.3 million, increased $15.6 \%$ compared with that of the previous identical time (the first three months of 2003). ${ }^{198}$ Antidumping investigations of Chinese goods bring dramatically negative impacts on China, such as resulting in significant difficulties for Chinese companies to enlarge their international market, and worsening Chinese international trade surroundings.

\footnotetext{
198 "Why China's market economy becomes a hot topic in the trade difficulties between the U.S. and the P. R. China?", China's Economy, on June $10^{\text {th }}, 2004$, available online: <http://www.ah 163.net/news/news.php3?id=74595>.
} 
Antidumping law is used for two reasons. First, as explained in section 1 of Part II, although the objective of antidumping law is stimulating international competition by opposing private firms' unfair activities, there is a gap between this objective and its real practice. In practice, antidumping investigations are full of techniques that are biased in favor of finding dumping and larger dumping margins. Thus, other countries can abuse the techniques to investigate Chinese goods in order to protect their domestic producers' interests, not only to limit predatory pricing by Chinese firms.

Second, to become a member of the WTO (rooted in market economy membership), China made an important concession that makes China an easier target country for other countries' antidumping investigations. ${ }^{199}$ Other countries can choose a third country with a similar level of development and similar resources to calculate the so-called actual non-market products' costs. While, as stated in section 1.1 of Part II, though having certain similarities, countries will have significant different prices because of the effects from different tariff structures or different patterns of consumption and production. The subjective selection can be a device for determining dumping and enlarging dumping margins.

Based on the abuse of antidumping cases on Chinese goods and their

\footnotetext{
199 The concession is section 15 of the protocol on the accession of the People's Republic of China. It states, "in determining price comparability under Article VI of the GATT 1994 and the Anti-Dumping Agreement, the importing WTO Member shall use either Chinese prices or costs for the industry under investigation or a methodology that is not based on a strict comparison with domestic prices or costs in China based on the following rules...ii) The importing WTO Member may use a methodology that is not based on a strict comparison with domestic prices or costs in China if the producers under investigation cannot clearly show that market economy conditions prevail in the industry producing the like product with regard to manufacture, production and sale of that product". See "Protocol on the Accession of the People's Republic of China", Ministry of Commerce of the People's Republic of China, available online: <http://www.mofcom.gov.cn/table/wto/law02.doc>.
} 
significantly negative impacts on China, from the perspective of Constitutive theory, there is a social need for reducing and even eliminating the misuse of antidumping law by foreign countries. From the above, one might think that China would support the Canadian proposal, namely, giving up antidumping law and replacing it with competition law.

However, there is another social necessity of China that is protecting domestic producers' interests by restricting imports. The protection social requisite has been reflected by a set of political traits or policies. The Chinese government is actively preparing to increase two kinds of abilities: 1) abilities to challenge other countries' antidumping investigations, and 2) abilities to practice antidumping law to protect domestic producers' interests. The development of the two types of capabilities implies that between the two different social requirements, the government of China prefers protection of domestic producers' interests to decreasing and even removing antidumping investigations initiated by other states, and does not favor replacing antidumping law with competition law. The following will consider the policies on improving the two kinds of capabilities.

When China is a respondent in antidumping cases, the government of China highlights two policies. First, the Chinese government stresses the improvement of domestic producers' consciousness on the active response to antidumping investigations. Mainly due to unfamiliarity with international business law, lack of confidence on winning lawsuits and insufficient funds, at 
least $50 \%$ of Chinese companies did not respond to antidumping cases. ${ }^{200}$ To deal with this problem, the Chinese government has implemented a policy that is rewarding companies that actively respond to antidumping investigations and punishing firms that do not respond or passively respond to antidumping cases. $^{201}$ With the practice of this reward-punishment policy, Chinese firms are now responding to antidumping cases more vigorously.

Second, an industrial alliance is beneficial to challenge other states' antidumping investigations. For example, in 2003, fifteen domestic lighter producers responded together to the EU's antidumping investigation on a plastic lighter. They explained that the Chinese plastic lighter would not lead to injury on the metal lighter industries because between a metal and a plastic lighter, there was a huge difference on the lighter's material, process, structure, standard and price. Based on the strong proof, in September 2003, the EU officially announced the end of the investigation on the lighter. This was the first antidumping case won by China, after becoming a member of the WTO. ${ }^{202}$ Similarly, when the U.S prepared to investigate antidumping of Chinese furniture in 2003 , the furniture industry in the mainland, Hong Kong and Taiwan got together, organized an alliance and assembled 150 million U.S. dollars to respond to the investigation. ${ }^{203}$

\footnotetext{
200 "How about China's ability to practice antidumping law?", Fujian Academy of Social Science, on September $3^{\text {rd }}, 2005$, available online: <hitp://fass.net.cn/fassNews/fass_readnews.asp?NewsID=624>.

201 "Measures for China to deal with antidumping investigations", Chinese Academy of Sciences, in March 2002, available online: <http://www.cas.ac.cn/html/Dir/2002/04/23/6184.htm>.

202 "China is also learning how to practice antidumping law for protection", China's Economy, on December $13^{\text {th }}$, 2002, available online: <http://finance.sina.com.cn/o/2003/212/1808559757.shtml>.

2013 Ibid.
} 
The above two examples clearly reveal the importance of industries' alliances. To benefit from the significant power of industries' alliances for dealing with other countries' antidumping investigations, such as the development of financial capabilities, it is necessary for China to energetically promote industries' alliances.

With regard to the ability to practice antidumping law to protect domestic producers' interests, at present, China has become the tenth most active user of antidumping law. The number of antidumping investigations initiated by China would be increased even further by the practice of the following four policies. Firstly, the Chinese government emphasizes that compared with advanced economies' antidumping laws, which are complete and subtle, Chinese antidumping law is superficial and abstract; thus, it is necessary for China to use developed countries' antidumping laws for reference in order to strengthen its antidumping law, to truly reflect Chinese reality, to guard particular domestic producers' interests and to guard against other countries' criticism. $^{204}$ The work on establishing a complete and subtle Chinese antidumping law can be a process of setting up bias in favor of finding dumping and enlarging dumping margins.

Secondly, the government of China states that it is necessary to develop related administrative functions (in the Ministry of Commerce). The functions should include following investigations and evaluating the influence of

${ }^{204}$ Chinese Academy of Sciences, Supra note 201. 
practicing antidumping law; completing the assessment system on injury, such as improving abilities on collecting data and calculating methods; inspecting and analyzing the international economy, particularly the impacts on domestic industries and competitiveness from abnormal exports and imports; and regularly publishing industries' competitiveness at the international level for supporting guides on investigating injury and assessing the effects of practicing antidumping law. ${ }^{205}$ The improvement of these functions will bring a number of advantages for the Chinese government to evaluate whether its domestic industries are in dangerous positions in international trade, whether it is necessary to practice antidumping investigations, and what duty level is suitable. However, similarly, these improvements may increase the chance of China's becoming an applicant in antidumping cases.

Thirdly, the Chinese government states that it is necessary to guide Chinese firms to understand more and more what antidumping law is, and how to use it to protect their interests. ${ }^{206}$ The guidance will encourage domestic producers to implement antidumping law to protect their interests. The number of antidumping investigations initiated by China will be definitely increased.

Fourthly, the government of China underlines that since the number of people who work in antidumping investigations is only $10 \%$ of those in the EU, it is necessary for China to foster more trained personnel. ${ }^{207}$ Training

\footnotetext{
${ }^{205}$ Fujian Academy of Social Science, Supra note 200.

206 "The most favorite target of antidumping cases---China is initiating antidumping investigations", The Newspaper of International Finance, on December $12^{\text {th }}, 2003$, available online: $<$ http://news.xinhuanet.com/fortune/2002-12/13/content_658877.htm>.

207 Fujian Academy of Social Science, Supra note 200.
} 
professionals will not only increase China's abilities on responding to other countries' antidumping investigations, but also develop abilities on devising and using biased techniques to locate dumping and large dumping margins.

In summary, when China is a respondent in an antidumping case, the practice of the two policies on improving abilities to challenge antidumping investigations of other countries is aimed to protect domestic producers' interests. When China is an applicant in an antidumping investigation, the implementation of the four policies on developing capabilities to use antidumping law is also purposed to guard national producers' interests. These sets of policies, especially the policies on enhancing abilities on the application of antidumping law, reveal the social necessity of protection of domestic producers' interests, and put more weight on the protection needed rather than the elimination requisite. Therefore, on the basis of the Constitutive theory, though suffering more and more negative influence from other countries' antidumping investigations, China has no consciousness on giving up antidumping law. China seems to treat its antidumping law as a kind of trade law for protection rather than a competition law for competition; or seems to prefer industrial interest to competition interest. The existence of antidumping law and even its misuse are natural and necessary in Chinese society. The Chinese government needs the antidumping law to shield its producers from too much international competition, to provide time for domestic industries to adjust the economic structure, and to increase nationally international 
competitiveness for further international competition.

However, the Chinese government will seek reforms of the current antidumping law. For example, as explained in section 3 of Part II, China will support the prohibition of the practice of cumulation in order to reduce the number of antidumping cases. To reduce high dumping duties, the Chinese government will support limiting the discretion of national authorities to impose duties up to the dumping margins. To avoid the bias in favor of finding dumping, the government of China will highlight the importance on lowering statutory minima for profit and administrative overhead and removing a set of discrimination policies and measures, such as the refusal of individual treatment.

More important, when China becomes an applicant in antidumping investigations, the government of China has realized that although dumping results in detriments on the Chinese producers' interests, Chinese consumers may get gains from dumped goods. An antidumping action can save jobs for the directly impacted industry, but it can bring harm on downstream employees. In other words, China's antidumping actions can lead to benefits; while, at the same time, they can result in detriments, too. It is hard to decide whether China's use of antidumping procedures is good per se.

The Chinese government, therefore, points out that it is necessary to balance the benefits and detriments resulting from the practice of antidumping law, and it is important to realize the degree of practicing antidumping actions. 
It is necessary to implement antidumping law to protect domestic producers' interests, but it is also required to avoid too much protection since excessive protection will lead to extremely negative impacts on the domestic consumers' interests, other kinds of heavy detriments, such as unemployment in the downstream industries, and decreasing domestic producers' consciousness on the development of competitiveness, which will significantly result in detriments on the industries and the whole economy. Similarly, avoiding the negative influence from extreme protection implies other Chinese social necessities, such as defending consumers' interests and reducing unemployment rate. Based on the Constitutive theory, these avoidance and social requisites will affect Chinese antidumping law's contents and enforcement or China's attitude to the law as well.

To refrain from excessive protection or to master the appropriate degree of practicing antidumping investigations, as stated in section 3 of Part II, the government of China must shift its emphasis from the effects on restriction of imports to the influence on the whole national economic interest, to focus on "acceptable vs. unacceptable levels of trade or market share or import penetration" instead of drawing the distinction of "fair" or "unfair" trade, and to implement the "national economic interest" test or the "nation-wide cost-benefit analysis" to determine "the acceptable level on trade or market share or import penetration". 


\section{2 China's attitude to competition law}

\subsubsection{Reasons for lack of a comprehensive anti-monopoly law}

Before exploring the attitude of China to its competition law, it is useful to seek answers as to why the Chinese legislature delayed the introduction of an Anti-Monopoly law, although in 1994, Chinese officials announced their intention to promulgate an Anti-Monopoly Law. ${ }^{208}$ Also, before the Central People's Representation Meeting held in Beijing, in March 2005, discussion on establishing a competition law was a boiling topic in the media. People fiercely talked about the benefits to be gained from a competition law, such as enjoying cheaper prices for train and air tickets. However, the Anti-Monopoly law did not pass again. ${ }^{209}$

The priority on focusing on industrial policy is an essential reason for postponing the enactment of a Chinese Anti-Monopoly Law. Specifically, there are two fundamental views. One of the views ${ }^{210}$ holds that an Anti-monopoly law is something for the future. Now, it is too early to implement the law because China is still in the early stage of the market economy and its market system is not well developed. Most industries are not excessively highly concentrated, but rather the contrary. Major firms have not yet attained economies of scale. The theme of market competition should resist unfair competition such as cheating and vicious competition rather than to control industrial structure. The other view ${ }^{211}$ believes that the government should

\footnotetext{
208 Ping LIN, Supra note 78, at 23.

209 “The $10^{\text {th }}$ Central People's Representation Meeting", in March 2005, available online:

<http://cn.news.yahoo.com/2005lh_live_0307a/index.html>.

210 Ping LIN, Supra note 78, at 24.

211 Ibid.
} 
encourage forming large enterprise groups and promoting the development of economies of scale in order to increase Chinese enterprises' international competitiveness.

Although there are divergences of the two views, they have the common goal, namely, putting more weight on industrial policy rather than competition policy to have international competitiveness or to compete with foreign enterprises more efficiently. The selection of the priority, as with the choice made by Japan prior to the 1980s, absolutely discloses the essential social requirements of China. Namely, to maintain long-term economic development, it is necessary to put certain resources to given favored industries and to create and promote bigger operators in certain industries. These crucial social needs go against the principles of competition law, therefore, according to the Constitutive theory, the existence and enactment of Chinese anti-monopoly law is not natural and necessary.

\subsubsection{Chinese economic, social and political features}

With further economic globalization and international merger movements, is it necessary for China to set up a comprehensive competition law? If so, what will determine its objectives and contents? The Constitutive theory will answer the necessity or not of a Chinese competition law and its possible objectives and contents by focusing on China's economic, social and political features to locate China's social conditions and requisites. 


\section{- Economic traits}

The Chinese economy is subject to domestic, external and international pressures. With the "open door" policy, ${ }^{212}$ there are enormous economic structural changes that have occurred in China, especially privatization and deregulation. ${ }^{213}$ These domestic changes seem to indicate a need for China to enact its competition law to protect and further stimulate private competition, and to assess and improve the efficiency of the economy. ${ }^{214}$ In the international sphere, the present international merger movements bring a necessity of Chinese competition law as well since there are problems resulting from the increased market power of large multinationals and their potential abuse of dominance. For example, international mergers' monopoly power can affect China when a foreign multinational acquires a domestic firm, and can reduce the contestability of markets, which is especially harmful for certain Chinese firms that are building up their capabilities to compete in the international market.

However, there are other economic characteristics that disclose Chinese firms' low competitiveness at the international level and rejection of a Chinese comprehensive competition law. For example, although China has become the

\footnotetext{
212 The term “Open Door Policy" refers to equal trading rights among countries. In 1978, China planned to shift its centrally planned economy to a process of market-oriented reforms. The Chinese leader Deng Xiaoping announced the open door policy. It included four southern cities as Special Economic Zones (SEZs), which were Shenzhen, Zhuhai, Shantou, and Xiamen, to take advantage of their geographic proximity to overseas Chinese communities, such as Hong Kong, Taiwan and Macau and for their vast overseas connections. Foreign investment was encouraged and new factories were establishes in these SEZs by offering tax privileges, which were reduced import tariffs on raw materials, tax exemption for importation of certain capital goods, and so on. See "The Importance of Open Door Policy and its consequences in the economic development and society of Modern China", available online: <http://www.geocities.com/colamon1/colamon.WBP.html>.

${ }^{213}$ Ping LIN, Supra note 78, at 18-27.

214 Jack Glen \& Ajit Singh, Supra note 76, at 2.
} 
third major country in international trade, when compared with developed countries' enterprises, almost no Chinese firms have sufficient abilities to compete with them. Their production scale, production ability and their international competitiveness are lower. Specifically, the Chinese strongest 500 firms just have $8.4 \%, 7.0 \%$ and $6.0 \%$ as much revenue, profit and asset as the international strongest 500 corporations. ${ }^{215}$

Furthermore, as pointed out by the dean of Shanghai Social Science Department, the increase in GDP and exports does not mean the enhancement of Chinese competitiveness. That a large portion of exports is from foreign invested enterprises cannot represent Chinese competitiveness as well. He considers that foreign investment implies a positive recognition of the future of the Chinese economy and the potential for profits, not a definite recognition of the development of China's competitiveness. ${ }^{216}$ To truly reflect the competitiveness and welfare, it is more useful for China to consider GNP, ${ }^{217}$ since GNP can more exactly represent China's international competitiveness by analyzing Chinese firms' own investment to examine abilities of sharing and even penetrating foreign and international markets.

\section{- Social traits}

China has a long history of heavy government intervention in the market system by administrative guidance of flows of resources into selected

\footnotetext{
215 "The Publication of Chinese strongest 500 firms in 2005---there still is a huge gap on competition ability, compared with the International strongest 500 enterprises", on August $21^{\text {st }}, 2005$, available online: <http://politics.people.com.cn/GB/1026/3631680.html>.

216 "The development of GDP does not mean the improvement on social welfare", on August $26^{\text {th }}, 2005$, available online: <http://estate.chinanews.com.cn/news/2005/2005-08-26/26/617015.shtml>. 217 Ibid.
} 
industries or by running state-owned enterprises (SOEs) directly. On the enactment of competition law, there will be widespread domestic confrontations, especially from the SOEs. The influence of SOEs may delay the introduction of competition law or affect its scope and enforcement. For instance, in 1994, the Chinese legislature failed to enact the supplement Anti-monopoly Law because of the resistance from SOEs. ${ }^{218}$

Moreover, with the advantages from the "open door" policy, there are serious social pressures as well. For instance ${ }^{219}$, during 1998-2000, there were 16 million layoffs from the SOEs. It indicates that there is a huge challenge for China with the dismantling of the previous "iron rice bowl" system. Regional income disparity has also become a significant problem: the coastal regions get much more benefits from the "opening door" policy than those of the poor western and central regions. These social challenges have led to an argument, namely, whether these challenges could undermine the sustained and rapid economic growth and social stability. Additionally, like other Asian countries, China lacks a healthy competition culture, such as consumers' weak awareness of the relevance and importance of a competition law.

\section{- Political traits}

China is planning to become a strong country in the international trade community that focuses on the quality and technology of exports, not on the

\footnotetext{
218 Ping LIN, Supra note 78 , at 33-34.

2:9 Markus Rodlauer \& Paul Heytens, "Chapter 1: Introduction and Overview”, in Wanda Tseng \& Markus Rodlauer eds., China: Competing in the Global Economy. Available online:

<http://www.imf.org/external/pubs/nft/2003/china/>.
} 
quantity. $^{220}$ To attain this goal, the Chinese government considers that it is necessary to increase industries' concentration because it not only can save natural resources and effectively deal with trade difficulties, but can also promote competitiveness by increasing innovation.

As analyzed in section 3.4 of Part III, undue investment will result in inflation and negative impacts on keeping long-term rapid economic development such as falling profits, productivity and desire of further investment, thus, it is important to allow government involvement in investment decisions to prevent excessive competition. The Chinese government has developed sets of policies to channel foreign investment to the necessary industries and areas, and to lower the speed of investment, especially in real estate sectors. $^{221}$

It also seems that the current government puts more weight on maintaining balanced regional distributions of industry and reducing the unemployment rate than pure and rapid economic development. The Chinese political decisions are represented by a speech, given by Premier Jiabao, Wen, in the $21^{\text {st }}$ Century Forum. The speech emphasizes that China will put stimulating domestic consumption as the most important way to develop its economy, not focusing on investment; will increase the speed in adjusting economic development models; will develop innovation abilities; and pay

\footnotetext{
220 "Possible for long-term economic development", on September $7^{\text {th }}, 2005$, available online: <http://cppcc.people.com.cn/GB/34952/3676355.html>.

221 "International economists' opinion---there are four problems for China to deal with to sustain the development of economy", China's Investment, on August $22^{\text {nd }}, 2005$, available online:

<hitp://gov.finance.sina.com.cn/zsyz/2005-08-22/67446.html>.
} 
attention to building a harmonious society that is reducing the amount of poor people and narrowing the gap between the rich and the poor. ${ }^{222}$

\subsubsection{China's attitude to competition law}

By analyzing the economic characteristics of China, there are two different social necessities. One is asking for the enactment of Chinese anti-monopoly law because of domestic requirements from privatization and deregulation, and international pressures largely from the current international merger movements. In other words, to protect and to further stimulate private competition, to deal with market dominance, abuse of dominant positions and reduction on the contestability of international markets, it is necessary for China to set up its competition law.

The other one, however, stresses the priority on industrial policy rather than competition policy/law, and begs for postponing the introduction of Chinese competition law. This social necessity highlights that to maintain long-term economic development and to become a powerful country in international trade, it is necessary for China to have international competitiveness by fostering strong national enterprises at the international level.

Based on China's social traits, we can definitely draw a conclusion that China lacks a healthy competition culture. Business lobbies have strong inclinations to go against the practice of competition law. Chinese consumers are not quite aware of the relevance and importance of competition law/policy.

222 Ibid. 
The sets of social challenges, such as unemployment and regional income disparity, make the introduction of Chinese anti-monopoly law more complicated and controversial. For example, firms in the poor regions will deny the enactment of competition law. They will argue that their competition ability is lower compared with corporations in the rich regions of China, and underline that the competition is unfair because only equal starting levels result in equal outcomes. The statements, given by the firms in the poor regions of China, are quite similar with the accounts that are announced by the developing countries' opinion on the implementation of their competition laws. The only difference could root in the diverse realms' comparison, namely, in the national sphere or in the international sphere.

Also, if there were a Chinese anti-monopoly law, the Chinese government would face multiple objectives, like South Africa, stated in section 3.2 of Part III. A pro-competitive merger may be stopped because of its employment influence. When deciding whether to permit a merger, a Chinese agency has to think about the effects of the transaction, such as the impacts on employment and distribution. The agency has to evaluate and balance a set of conflicting ends. In a word, faced with the confused issues, it is hard for the Chinese legislature to put a Chinese anti-monopoly law into practice rashly.

The political features of China imply that the essential social needs again must be taken into account, namely, paying attention to practicing industrial policy to develop certain industries' competition ability in order to efficiently 
compete with advanced economies' corporations in the international realm. The political traits, such as building a harmonious society, also reflect the social requirement on dealing with the social challenges that may undermine the long-term economic development of China, and stress avoiding too much investment, which, as further analyzed below, will affect the introduction of Chinese anti-monopoly law and its objectives and contents.

Based on the statements of China's economic, social and political features in section 2.2.2 and the above analyses, from the perspective of Constitutive theory, it is submitted that the Chinese legislature is not interested in practicing a comprehensive anti-monopoly Law. The essential reason is that, due to low international competitiveness or the fundamental social necessity of fostering powerful national firms to compete with developed countries' enterprises more efficiently, putting competition law into practice will make it difficult for domestic firms to coordinate strategies, and reduce abilities of domestic companies to become internationally competitive. When there are conflicts between competition interest and industrial interest, the government of China will prefer industrial interest to competition interest. The Chinese government believes that to equally compete with advanced economies' enterprises, the first thing for China to do is to allow resources to certain industries and mergers, to develop larger enterprises in given industries, and to appropriately restrict new entries into certain industries. Increasing international competitiveness can be the most important factor for the long-term economic development. 
Besides the above basic reason or social need, since the government of China also understands the detriments from too much investment, such as inflation and diminishing people's desire to invest, and because of the lack of a competition culture, especially the SOEs' objection, the Chinese government will not enact its competition law until it is unable to bear more pressures from domestic, external and international sources. When that point is attained, China will enact an anti-monopoly law. However, both its objectives and contents should be consistent with its final aim to maintain long-term economic development.

No matter whether the Chinese legislature treats competition law separately from competition policy, or as a part of competition policy (the Egyptian option), the objective of China's anti-monopoly law will not simply focus on the promotion of competition, but will seek to foster economic development. It will imply the importance of the economic dynamic or maximization of "public interest" rather than static efficiency or maximum competition because of the social requirements of avoiding too much investment, balancing distribution, and establishing a harmonious society to sustain long-term development of the economy. The objective will underline a belief, which is stated in the Preamble of the WTO, namely, "trade and economic endeavor should be conducted with a view to raising the standards of living, ensuring full employment and a large and steadily growing volume of 
real income and effective demand". 223

The contents of China's anti-monopoly law should contain provisions on confining governments' anti-competition behaviors; restricting domestic firms' anti-competition actions; limiting multilateral enterprises' abuse of monopoly power; and promoting long-term economic development. ${ }^{224}$ More important, according to the Constitutive theory, faced with the above-stated essential social necessity, the contents should avoid dangers resulting from areas where it is not appropriate to focus on the pursuit of competition. That means that it is necessary for the Chinese legislature to exclude certain industries that are usually the basic ones for economic development with low international competitiveness. Similarly, based on social requirements of reducing conflicts between competition interest and industrial interest, saving social problems, maintaining people's desire to invest, and avoiding excessive competition, from the perspective of Constitutive theory, China's anti-monopoly law should not underline maximum competition, but emphasize an optimum competition that combines competition and cooperation among firms, and cooperation between government and business.

At present, motivated by both economic and political interests, local government leaders often protect local firms through various means, such as creating regional trade barriers and making the "playing field" tilted in favor of

\footnotetext{
223 Ajit Singh, Supra note 87, at 15 .

224 Ping LIN, Supra note 78 , at 18-27.
} 
local firms. ${ }^{225}$ To develop the economy, there is a social need, namely, breaking the prevalence of regional protectionism. Therefore, according to the Constitutive theory, curbing local governments' anti-competition behaviors will be the unique characteristic of the Chinese anti-monopoly law. Four kinds of administrative monopoly exist: forced transaction, regional blockade, sectoral monopoly, and compulsory associations that restrict competition. Among them, regional monopoly and sector monopoly are the most prevalent. ${ }^{226}$

Regional monopolies are created and protected by trade barriers erected by provinces and regions. Local protectionism bans the entry of goods and services into the local market, or prevents local raw materials or technology from being exported to other regions. ${ }^{227}$ Sectoral monopoly takes the form of large enterprise groups integrating administrative and business functions that bear a regulatory role over the sectors. It also includes enterprises that are directly affiliated with government ministries or departments and receive preferential treatment. ${ }^{228}$ Public utilities, backed by their advantages as natural monopolies, also have types of administrative monopolies. Operators in sectors such as water, power, gas, postal services, telecommunications, civil aviation, and railways use laws and government regulations as a cover to preclude competition and intrude on the interests of consumers. ${ }^{229}$

When the Chinese anti-monopoly law is put into practice, will its

\footnotetext{
225 Ibid. at 25-26.

226 Ibid. at 24 .

227 Ibid.

228 Ibid.

229 Ibid.
} 
enforcement be stringent? If the Chinese legislature enacts its competition law largely due to external and international pressures, not domestic requirements, the enforcement of the Chinese competition law will not be tight, which will be similar with the Japanese enforcement of its AMA, particularly prior to the 1980s. The primary reason is that to increase Chinese enterprises' international competitiveness and to maintain long-run economic development, the government of China will prefer industrial policy to competition policy. Exception cartels or mergers will be allowed. On the contrary, if the Chinese government puts its competition law into practice mainly because of internal interest, the enforcement of the Chinese competition law will be stringent, which is similar with the Japanese AMA enforcement, since the 1990s. The essential reason for the strict enforcement is that the Chinese economy needs the stringent enforcement to maintain its economic development and increase international competitiveness.

\subsection{China's attitude to a possible international competition law}

As stated in section 2.2.3 of this part, the Chinese legislature is not interested in the implementation of a comprehensive anti-monopoly Law. Likewise, on the basis of the Constitutive theory, China will not support the enactment of an international competition law when its objectives and contents are contrary to China's interest. There are two primary reasons. First, the implementation of an international competition law will require China to adopt its competition law to meet the standards of the international competition law. 
Second, if the international competition law's objectives and contents are contrary to the Chinese requirements, there would be negative impacts on the Chinese economy.

For example, it would be difficult for China to maintain its economic development, if the EU's proposal or the WGITCMGTCP's recommendations (stated in section 2 and 3 of Part IV), especially the national treatment and market access principle, are put into practice. To increase international competitiveness, it is necessary for the Chinese government to nurture, subsidize and encourage domestic firms and to protect local firms from free international competition. The national treatment principle goes against these necessities, the development perspective and the ultimate goal.

The national treatment principle also violates fair competition in the international market since only an equal starting point can lead to equal competition. Different international competitiveness, as a precondition, will lead to different outcomes of international competition. Currently, China's international competitiveness is low. That means that there is a lack of the precondition for Chinese firms to equally compete with advanced enterprises. To fairly take part in international competition, it is necessary for the Chinese corporations to gain the vital prerequisite, namely, at the international level, having equal or at least similar competition abilities with those of developed enterprises. It is necessary for the Chinese government to deliberately nurture, subsidize and encourage local firms to promote their competitiveness in the 
international sphere. However, the national treatment vetoes the Chinese social requirements. It is inappropriate for China to implement preference approaches to its firms to gain the equal prerequisite.

Both the EU's proposal and the WGITCNGTCP's recommendations aim to maximize the rights of foreign enterprises to have market access to China, which pays attention to investment rather than products. However, at present, Chinese companies have less ability and interest to invest abroad. For instance, until 2004, the Chinese direct investment in foreign countries was 370 billion U.S. dollars, which is only $6.58 \%$ of foreign direct investment in China. According to the UN's Report on International Investment 2003, the Chinese direct investment in the rate of flow and the rate of deposit was just $0.45 \%$ and $0.48 \%$, which was lower than those of developed economies and even the average rate of developing countries. ${ }^{230}$ Thus, the government of China is not interested in whether there is market access for its domestic enterprises, or whether its national firms operating overseas are protected by a competition regime in a host economy.

On the contrary, based on the sets of social necessities and the Constitutive theory, the Chinese government is more concerned about stimulating local firms' promotion in competitiveness by a set of government assistance programs or policies, curbing mega-mergers and acquisitions to protect local companies' competitive positions in the international competition

\footnotetext{
230 "China's Brand---problems behind the glory", on September 6", 2005 , available online: <http://finance.people.com.cn/GB/1045/3670681.html>.
} 
sphere, and restricting business practices of foreign multinationals, such as price-fixing or bid rigging that lead to higher prices of imported products or services. Therefore, if the objective of a possible multilateral competition law pays attention to curbing the international merger movements and restricting multinationals' anti-competitive practices, the government of China would support it.

In short, the Chinese government, focused on its own social necessities, will definitely oppose market access at the international level as long as its domestic enterprises do not have the equal abilities to compete with those of advanced economies. However, in order to develop the economy, the Chinese government has permitted market access in the national realm through removing administrative barriers among cities' and provinces' competition. ${ }^{231}$ As discussed in section 2.2.3 of this part, provisions on banning governments' anti-competition behaviors, such as forced transaction, regional blockade, sectoral monopoly, and compulsory associations that restrict competition have reflected the permission of national market access.

\footnotetext{
${ }^{231}$ Ping LIN, Supra note 78, at 19-22.
} 


\section{Conclusion}

From the perspective of Constitutive theory, law, as part of a society, is authoritative, and is shaped by society. The relationship between law and society is reciprocal. The enactment and development of a law tie on its social internal necessities, not external pressures, such as compulsion by the state. A law will exist as long as there is a natural and necessary demand in a society in which the law is embedded. It is important for law to become realistic and implementable, not futile and even counterproductive. Therefore, as long as legislatures pass laws, it is necessary for them to take into account their countries' economic and industrial development stages, political and social conditions, and cultural considerations. When there is a difference on the above aspects among countries, economies will have different opinions on a law's purposes and contents, especially on transnational issues like trade and competition policies. There is no exception for China. The eventual aim for China is to sustain long-term economic development, therefore, the practice or not of antidumping law, competition law and possible international competition law, and their enforcement, are just means to gain the final goal.

Based on the analyses in Parts II, III and IV, low international competitiveness is the most important element to determine the attitude of China on antidumping law, competition law and a possible international competition law. Because of low competitiveness at the international level, though suffering significant harm from other countries' antidumping 
investigations, it is hard for the government of China to easily support the Canadian proposal, namely, replacing antidumping law with competition law. The Chinese government needs to implement antidumping law to protect certain industries and to allow time for specific industries to increase their international competition abilities.

The low international competitiveness requires the Chinese government to comprehend the importance of the coherence between industrial policy and competition policy; to emphasize its competition law on the basis of dynamic efficiency rather than static efficiency; and instead of maximum competition, to highlight the combination between competition and cooperation among firms, and between business and government.

Due to low international competitiveness, the government of China does not care about its domestic enterprises' protection by a possible international competition law, and rejects the EU's proposal and the WGITCMGTCP'S recommendations, especially the national treatment principle and market access at the international level. On the contrary, the Chinese government, to maintain long-term economic development and to get equal competition abilities at the international level, strives to nurture, subsidize and encourage domestic firms, to curb mega-mergers and acquisitions, and to restrict business practices of foreign multinationals, such as price-fixing or bid rigging. Although China puts antidumping law as a kind of trade law for protection and adopts kinds of government assistance and protection to promote 
international competitiveness, the Chinese government underlines that it important to measure the degree of protection since too little protection will threaten the survival of domestic firms in the international sphere, and too much protection will decrease domestic producers' consciousness of the development of competitiveness, and lead to detriments on industries and the whole economy.

Also, almost every economy puts antidumping law as a kind of trade law for protection. Almost no country can practice totally free and fair international competition. Therefore, it is reasonable to implement acceptable vs. unacceptable levels of trade or international market access instead of practicing fair or unfair measures. It is positive for the governments to shift their emphases from the effects on restricting of imports to the influences on the whole national economic interest. The implementation of the "national economic interest" or the "nation-wide cost-benefit analysis" test could be the best method to determine the acceptable level of trade or international market access. 


\section{Bibliography}

"Agreement on implementation of Article VI of the General Agreement on Tariffs and Trade 1994". The World Trade Organization. Available online: <http://www.wto.org/english/docs_e/legal_e/19-adp_01_e.htm>.

Arnold, Bruce Gregory. How the GATT affect(s) U.S. antidumping and Countervailing---Duty Policy (The Congress of the United States: Washington D.C., 1994).

"Article VI Anti-dumping and Countervailing Duties". Available online: <http://www.marxists.org/history/capitalism/gatt/ch06.htm>.

"Asian Development Outline 2005: III. Promoting competition for Long-term development". Asian Development Bank. Available online: <http://www.adb.org/Documents/Books/ADO/2005/part030300.asp>.

"Canadian Federation Of Agriculture Trade Policy Statement: Introduction". Chicken Farmers of Canada. Available online: <http://www.chicken.ca/DefaultSite/index_e.aspx?DetaillD=97>.

"China's Brand---problems behind the glory". On September 66 2005. Available online: <http://finance.people.com.cn/GB/1045/3670681.html>.

"China is also learning how to practice antidumping law for protection". China's Economy, on December $13^{\text {th }}$, 2002. Available online: <http://finance.sina.com.cn/o/20031212/1808559757.shtml>.

"Chairman's Speech". The Cotton Textiles Export Promotion Council (TEXPROCIL), on September $21^{\text {st }}$, 2004. Available online: $<$ http://texprocil.com/speech1.htm>.

Choudry, Aziz. "Another Corporate Steal? The Proposed WTO Competition Policy”, 2004. Available online: <http://www.incsoc.net/asean-rep.doc>.

"Competition policy as a dimension of economic policy: a comparative perspective". Industry Canada. Available online: <http://strategis.ic.gc.ca/epic/internet/ineas-aes.nsf/vwapj/op07e.pdf/\$FILE/op 07e.pdf>.

Dean, Bahaa Ali El \& Mohieldin, Mahmoud. "On the Formulation and Enforcement of Competition Law in Emerging Economies: The Case of Egypt". Available online: <http://www.eldis.org/static/DOC11407.htm>.

"Declaration by the Group of 77 and China on the Fourth WTO Ministerial 
Conference at Doha, Qatar". The Group of 77 at the United Nations. Available online: <http://www.g77.org/Docs/Doha.htm>.

Devuyst, Youri. "Toward a Multilateral Competition Policy Regime" (2000) 6 Global Governance. 319-38.

"Doha WTO Ministerial 2001: Ministerial Declaration". The World Trade Organization. Available online: <http://www.wto.org/english/thewto_e/minist_e/min01_e/mindecl_e.htm\#trips $>$.

Fikentscher, Wolfgang. "Collaborative Activities among Industrial Competitors---in German, European, and U.S. Antitrust law, and in the Draft International Antitrust Code in the GATTMTO system", in Chia-Jui Cheng eds., International Harmonization of Competition Laws (Martinus Nijhoff Publishers: Dordrecht, 1995).

Fu, Donghui. "EC Antidumping Law and individual Treatment Policy in Cases involving Imports from China" (1997) 31(1) Journal of World Trade. 73-105.

Glen, Jack \& Singh, Ajit. "Corporate Governance, Competition, and Finance: Re-thinking lessons from the Asian Crisis" Spring 2005 Eastern Economic Journal. 219-43. Available online: <http://www.findarticles.com/p/articles/mi_qa3620/is_200504/ai_n14904760>.

Ghoneim, Ahmed Farouk. "Competition Law and Competition Policy: What does Egypt Really Need?". Economic Research Forum. Available online: $<$ http://www.erf.org.eg/nletter/Newsletter_Winter02/NewsletterWinterlssue03P18.pdf>.

Hoekman, Bernard M. Mattoo, Aaditya \& English, Philip. "Development, Trade, and the WTO: A Handbook". Available online: <http://www.amazon.com/gp/product/082134997X/104-1518953-6263138?v= glance $\& n=283155 \& v=$ glance $>$.

Hoekman, Bernard M. \& Mavroidis, Petros G. "Dumping, Antidumping and Antitrust" 1996 30(1) Journal of World Trade. 27-52.

“How about China's ability to practice antidumping law?". Fujian Academy of Social Science, on September $3^{\text {rd }}$, 2005. Available online: $<$ http://fass.net.cn/fassNews/fass_readnews.asp?NewsID=624>.

"International economists' opinion---there are four problems for China to deal with to sustain the development of economy". China's Investment, on August $22^{\text {nd }}$, $2005 . \quad$ Available online: 
<http://gov.finance.sina.com.cn/zsyz/2005-08-22/67446.html>.

Ireland, Derek J. "Antidumping and Competition Policy Rules". Competition Bureau. Available online: $<\mathrm{http}: / /$ www.competitionbureau.gc.ca/internet/index.cfm?itemID=1073\&lg=e>

Kennedy, Kevin. Competition Law and the World Trade Organization: the Limits of Multilateralism (Sweet \& Maxwell: London, 2001).

Krishna, Raj. “Antidumping in Law and Practice”. The World Bank, 1997.

Lewis, David. "Competition Regulation: The South African Experience". Competition Tribunal. Available online: <http://www.comptrib.co.za/Publications/Speeches/Teipei\%20Conference\%20 Speech.htm>.

LIN, Ping. "Competition Policy in East Asia: The Cases of Japan, People's Republic of China, and Hong Kong". The World Bank: Paper and Links, 2001. Available online: <http://rru.worldbank.org/PapersLinks/Developing-Competition-Policy>.

Masiiwa, Medicine. "Statement on the WTO DOHA Ministerial Declaration". Trade and Development Studies Center (TRADES). Available online: $<$ http://www.sarpn.org.za/CountryPovertyPapers/Zimbabwe/may2002/trade.ph p>.

Mathis, James H. "Competition and Regulation Policies in the WTO: Implications of a Multilateral Competition Policy Framework". Jamaica Fair Trading Commission. Available online:

<http://www.jftc.com/events/10th\%20Anniversary/SPLJames\%20Mathis\%20L ecture\%20powerpoint\%20show.ppt>.

"Measures for China to deal with antidumping investigations". Chinese Academy of Sciences, in March 2002. Available online: <http://www.cas.ac.cn/html/Dir/2002/04/23/6184.htm>.

Mehta, Pradeep S. "Competition Policy in Developing Countries: An Asia-Pacific Perspective". Bulletin on Asia-Pacific Perspectives 2002/03. Available online: <http://www.unescap.org/pdd/publications/bulletin2002/ch7.pdf>.

Minh, Tran Duc. "Capacity---building for Post-Doha Pre-Negotiations: Regional Seminar on Competition Policy and Multilateral Negotiations". Available online: <http://r0.unctad.org/en/subsites/cpolicy/gvaJuly/docs/en15.doc>. 
Mutume, Gumisai. "New WTO proposals stir controversy: Singapore issues could undermine local enterprises in Africa". Africa Recovery. Available online: <http://www.un.org/ecosocdev/geninfo/afrec/vol17no4/174wto.htm>.

Neufeld, Inge Nora. Antidumping and Countervailing Process ---Use or Abuse implications for developing countries (New York: United Nations, 2001).

Niels, Gunnar \& Kate, Adriaan ten. "Trusting Antitrust to Dump Antidumping: Abolishing Antidumping in Free Trade Agreements without Replacing it with Competition Law" (1997) 31(6) Journal of World Trade. 29-43.

Nikomborirak, Deunden. "VI: Competition Policy in the World Trade Organization: How to make it a developing country's agenda". United Nations Economic and Social Commission for Asia and the Pacific. Available online: $<$ http://www.unescap.org/tid/publication/chap6_2278.pdf >.

"OECD Global Forum on Competition---the objectives of competition law and policy and the optimal design of a competition agency". Center for Co-operation with Non-members directorate for Finance, Fiscal and Enterprise Affairs. Available online: <http://www.oecd.org/dataoecd/58/25/2485968.pdf>.

"Possible for long-term economic development". On September $7^{\text {th }}, 2005$. Available online: <http://cppcc.people.com.cn/GB/34952/3676355.html>.

"Protocol on the Accession of the People's Republic of China". Ministry of Commerce of the People's Republic of China. Available online: <http://www.mofcom.gov.cn/table/wto/law02.doc>.

Rodlauer, Markus \& Heytens, Paul. "Chapter 1: Introduction and Overview", in Wanda Tseng \& Markus Rodlauer eds., China: Competing in the Global Economy. Available online: <http://www.imf.org/external/pubs/nft/2003/china/>.

Sarat, Austin. "Discussion: Pain, Powerlessness, and the Promises of Interdisciplinary Legal Scholarship: An Idiosyncratic, Autobiographical Account of Conflict and Continuity" (2000) 18 Windsor Y.B. Access Just. 187-212.

Sarat, Austin \& Kearns, Thomas R. "Beyond the Great Divide: Forms of Legal Scholarship and Everyday Life", in Austin Sarat \& Thomas R. Kearns eds., Law in Everyday Life (The University of Michigan Press: Ann Arbor, 1993). 21-62.

Singh, Ajit. "Competition and Competition Policy in Emerging Markets: International and Developed Dimensions". The World Bank: Papers and Links, 
2001.

Available

online:

<http://rru.worldbank.org/PapersLinks/Developing-Competition-Policy>.

Singh, Ajit \& Dhumale, Rahul. "Competition Policy, Development and Developing Countries". South Center--- An Intergovernmental Organization of Developing Countries. Available online: $<$ <ttp://www.southcentre.org/publications/competition/toc.htm>.

Singh, Digvijay. "Reflections on Doha Ministerial of the WTO: Issues and Options". Federation of Indian Chambers of Commerce and Industry (FICCI). Available online: <http://www.ficci.com/ficci/media-room/speeches-presentations/2001/aug/aug 27-wto-digvijaysingh.htm>.

"Textiles and Clothing---Who Gains, Who Loses, and Why?" (1997) 5 Briefing Paper. CUTS International. Available online: $<$ http://www.cuts-international.org/1997-5.htm\#Anti-dumping\%20under\%20the $>$.

"The Economic and Political Case for Privatization". Enterprise Development Impact Assessment Information Service (EDIAIS). Available online: $<$ http://www.enterprise-impact.org.uk/word-files/Privatisation-2-Section1.doc>.

"The development of GDP does not mean the improvement on social welfare". On August $26^{\text {th }}$, 2005 . Available online: <http://estate.chinanews.com.cn/news/2005/2005-08-26/26/617015.shtml>.

"The Importance of Open Door Policy and its consequences in the economic development and society of Modern China". Available online: <http://www.geocities.com/colamon1/colamon.WBP.htmls.

"The most favorite target of antidumping cases---China is initiating antidumping investigations". The Newspaper of International Finance, on December $12^{\text {th }}$, 2003. Available online: <http://news.xinhuanet.com/fortune/2002-12/13/content_658877.htm>.

“The $10^{\text {th }}$ Central People's Representation Meeting". In March 2005. Available online: <http://cn.news.yahoo.com/2005lh_live_0307a/index.html>.

"The Publication of Chinese strongest 500 firms in 2005---there still is a huge gap on competition ability, compared with the International strongest 500 enterprises". On August $21^{\text {st }}$, 2005. Available online: <http://politics.people.com.cn/GB/1026/3631680.htmls.

"TWN Cancun Briefings 5-Trade and Competition Policy in the WTO". TWN 
Africa. Available online: <http://twnafrica.org/news_detail.asp?twnID=495>.

Vautier, Kerrin M. "Competition Policy, Developing Countries and the WTO", $1999 . \quad$ Available online:

<http://papers.ssrn.com/sol3/papers.cfm?abstract_id=200621>.

Vermulst, Edwin \& Driessen, Bart. "New Battle Lines in the Anti-Dumping War ---Recent Movements on the European Front" (1997) 31(3) Journal of World Trade. 135-57.

Whish, Richard. Competition Law $3^{\text {rd }}$ ed. (Butterworths: London, 1993).

"Why China's market economy becomes a hot topic in the trade difficulties between the U.S. and the P. R. China?". China's Economy, on June 10 $10^{\text {th }}, 2004$. Available online: <http://www.ah163.net/news/news.php3?id=74595>.

Yngvesson, Barbara. "Inventing Law in Local Settings: Rethink Popular Legal Culture" (1989) 98 Yale L. J. 1689-1709.

Young, Linda M. \& Wainio, John. "The Antidumping Negotiations: Proposals, Positions and Antidumping Profiles" (2005) 6 (1) Journal of International Law and Trade Policy. 23-46. 